\title{
Sectoral Demand for Petroleum in Thailand
}

November 14, 2009

\author{
Poonpat Leesombatpiboon and Fred Joutz \\ The George Washington University \\ Department of Economics \\ poonpat@gwu.edu and bmark@gwu.edu
}

\begin{abstract}
This paper examines the short-run and long-run effects determinants final oil consumption in seven major economic sectors in Thailand. Two different approaches are compared. The first approach uses dynamic panel data estimation techniques taking into account oil consumption of the whole economy in an aggregate manner. The second approach employs the ADL error correction framework to model oil demand in each economic sector separately. The results show that the dynamic panel data approach appears to give estimates consistent with the economic theory. The signs on the coefficients are correct and the magnitude of long-run responses is larger than that of the short-run responses. The single sector model approach yields similar but richer results. Since constant slopes are not imposed across sectors the characteristics and dynamics and responses can differ across sectors

Acknowledgements: We are grateful for the scholarship support from IAEE to participate in the $32^{\text {nd }}$ IAEE International Conference in San Francisco. David Ryan, Lester Hunt, Steven Brown, and Hill Huntington provided useful comments along with other participants at the $2^{\text {nd }}$ International Workshop on Empirical Methods in Energy Economics, Jasper, Alberta where an earlier version of this paper was presented. All errors and omissions are the authors.
\end{abstract}




\section{Introduction}

Thailand is a net energy-importing country. About 60 percent of the energy used is imported from abroad. Thailand's overall energy demand has grown substantially. The average growth rate has been about 7.0 percent per year for the past two decades. Economic growth has been slightly slower at an average of about 5.9 percent per year. Oil consumption has risen more than threefold since the year 1981 although the share of oil consumption in total energy consumption has dropped from 87 percent in 1981 to 60 percent in 2007. The importance of oil in the economy remains interesting for policy makers.

The purpose of this study is to examine the short-run and long-run demand elasticities for oil in seven major economic sectors of Thai economy including Agriculture, Construction, Electricity, Manufacturing, Mining, Residential \& Commercial and Transportation. The impact of oil price movements and shocks has differed across sectors. The main reasons are that the state of development and the specific characteristics like energy intensity and oil mix in consumption affect the degree of flexibility and adjustment of oil consumption in each sector.

Specifically speaking, these different characteristics might be due to the types of petroleum products consumed by each sector, the degree of substitutability with alternative energy for oil, the level of capital accumulation, output/ income generated and labor inputs (and government policies). These factors are vital for understanding the effects on oil consumption in each sector. Therefore, it is reasonable to take into account the impact of oil consumption in a disaggregate manner rather than using the traditional approach which considers the oil consumption for the aggregate economy.

There have been numerous empirical studies of oil demand in developed countries. However, oil demand models from a developing country perspective may require a different framework. This study modifies the oil demand model traditionally used in the literature for industrialized countries for the case of Thailand in two ways.

First, this study takes advantage of a sectoral database spanning 1980-2007 to estimate oil demand elasticities by using two approaches: the disaggregate approach i.e. the single sector demand model and the aggregate approach i.e. the dynamic panel data approach. By comparing the results from these two approaches, we can better understand the pros and cons of using these approaches to model oil consumption for Thai economy.

Second, not many studies of oil demand have taken into account the effects from the price of substitutes. The effect of energy substitution has played an increasing role in Thailand during the past decade due to the adverse impacts from excessively high oil prices. In this study, the effects of alternative energy prices have been considered given the nature of each sector and the available information of substitute energy in the market. The replacement of oil by other types of fuels such as coal, natural gas and electricity can provide a better understanding of how alternative energy has affected the consumption behavior in each sector. 
"Oil consumption" in this paper refers to the "final" use of refined oil products not the "primary" use of all forms of petroleum energy. In other words, it focuses on the "final" users not the "primary" users. In the context of this study, there are seven major users which are represented by seven economic sectors as mentioned earlier. These sectors consume oil and produce goods and services. Only in the case of Electricity sector, oil is converted to be electricity which is considered as another form of energy.

We find that the dynamic panel data approach appears to give estimates consistent with the economic theory in that the signs are correct and the magnitude of long-run responses is larger than that of the short-run responses. Although using a panel data approach provides seemingly reliable results, the underlying assumption of forcing all sectors to behave in the same way might be too rigid and it might conceal interesting issues underlying consumption behavior in each sector.

As a result, we use an individual sector model approach to test the possible drawback of panel data approach. The individual sector model approach gives fairly reasonable estimates with sound statistical test results in all cases except in the Mining sector. We find the short-run and long-run income elasticities are positive in all cases except in the Transportation sector. The short run and long run labor elasticities are positive in all cases with the size in the long run larger than that of the short run in most cases except in the Electricity sector. Oil price elasticities are negative in the long run and short run for all sectors except in Electricity sector. As expected, Transportation sector's demand seems to be irresponsive to oil price change with almost the same magnitude for both short run and long run estimates.

It appears that the effect from the price of energy substitutes is not significant in the short run but the long run effects are varied from sector to sector. Positive long-run effect was found in Agriculture, Residential and Commercial and Manufacturing sector while negative long-run effect was found in Electricity sector. We interpret this as these alternative fuels appear to be complementary fuels in the Electricity sector while they are used as substitute energy in the Manufacturing sector. This finding is consistent to what has happened recently in these sectors.

Capital appears to have a negative long-run impact on oil consumption in all sectors except in Agriculture sector. But we only found a significant and negative short-run impact of capital only in Electricity sector. The negative impact from capital might be interpreted as a greater efficiency of oil consumption from better technology of production while the positive impacts from capital can be deemed as a result from the development process in which inefficient machines and equipment are still in use and the switching costs are prohibitive or opportunities are not available.

The remainder of this paper is organized into eight sections. Section II gives a review of literature on energy demand elasticities. Section III provides the theoretical review on energy demand elasticities. Section IV provides the background of Thailand's petroleum demand by economic sectors. Section V looks at the data source and the description of 
variables. Section VI describes the two methodologies used in this paper i.e. 1) the ADLECM, auto-distributed lag error correction mechanism approach and 2) the dynamic panel data estimation approach. Section VII discusses the empirical findings obtained from these two modeling approaches. Section VIII of the paper summarizes the findings of the paper.

\section{Literature Review on Energy Demand Elasticities}

Numerous studies measuring the elasticity of energy demand, particularly oil and petroleum products, have been done for developed and developing countries by using different methodologies and data sets. A comprehensive set of surveys on energy demand elasticities for developing countries has been conducted by Dahl (1993), Dahl (1994a) and Dahl (1994b). (There is a draft working paper in 2009.) From her survey work in Dahl (1993) and Dahl (1994a), she claims that demand for oil in developing countries is income elastic with the magnitude greater than 1.32, implying that with stable prices oil demand will grow at a faster rate than income. Conversely, the price elasticity of oil demand is inelastic at about -0.30 , implying that any policies to increase price to curb the rising demand will be effective only if the magnitude of price change is large enough.

In terms of total energy demand in developing countries, Dahl (1993) reports that Thailand's intermediate-run energy price elasticity is about -0.26 and the intermediaterun income elasticity is around 1.01. The results are estimated from the Generalized Least Squares method with the static model for the data set between 1973 and 1987. Dahl also suggests that using energy consumption per capita in the model is a preferable choice since aggregate consumption may cause a heteroscedasticity problem due to the variation in population across samples. It is also pointed out in Dahl (1993) that static models seem to produce the most variation across elasticities and have incorrect signs.

Frazen and Sterner (1995) estimate the long-run elasticities of demand for gasoline in OECD countries, using the OECD data covering the period from 1960 to 1988. They apply three different approaches i.e. time-series, cross-section and pooled estimation and then compare the estimate results from these three approaches. They claim that pooled estimators with dynamic specifications produce biased results while the cross-section estimators tend to give higher price elasticity values than time series estimators.

Dahl and Kurtubi (2001) estimate the oil product demand in Indonesia, using a co integrating error correction model for annual data from 1970 to 1995. They find strong evidence supporting the existence of a long-run cointegrating relationship between petroleum product consumption, its own price, and income. They report the long-run price for petroleum fuels as follows: aviation fuel (-1.2), gasoline (-0.6), kerosene $(-0.7)$, automotive diesel (-0.7), industrial diesel (-1.1) and total petroleum products (-0.6).

Vita, Endresen and Hunt (2005) conduct an econometric study of Namibian energy demand at the aggregate level and by energy type (including electricity, petrol and diesel), using an Autoregressive Distributed Lag (ARDL) approach for the period of 
1980-2002. The study shows that energy consumption responds positively to changes in GDP and negatively to changes in energy price and air temperature. However, they do not find evidence of significant cross price elasticities between different energy forms.

Ahmadian, Chitnis and Hunt (2007) estimate Iranian gasoline demand function using structural time series model with stochastic trend for the annual data from 1968 to 1998. The model starts from the general form of ARDL with a three year lag and eliminates insignificant variables by using the diagnostic tests. The results show that the long-run and short-run price elasticities are -0.74 and -0.19 respectively while the long-run and short-run income elasticities are reported at 1.25 and 0.32 .

Hoa (1992) estimates demand elasticities of six petroleum products i.e. petrol, kerosene, diesel, fuel oil, aviation fuel, and LPG for Thailand, using annual data in the period 19741987. Hoa constructs the generalized price-augmented working-based six equation model for six petroleum products and estimates own-price, cross-price and income elasticities for each petroleum product. The estimated results are presented in table 1. It can be seen that most of the estimated own-price elasticities are positive except for diesel and fuel oil. Although own-price elasticities for diesel and fuel oil are negative, they are not significant. The reason for positive own-price elasticities as claimed by the author is that they might be due to the effects of regulated prices of petroleum products for some period of the study. In terms of income elasticities, kerosene is found to be an inferior good with negative income elasticity while income elasticities for diesel and LPG are greater than unity.

Table 1: Thailand's own-price, cross-price and income elasticities of six petroleum products (1947-1987)

\begin{tabular}{|c|c|c|c|c|c|c|c|}
\hline & " Petrol & "Kerosene & "Diesel & Fuel oil & Asphalt & "LPG & Income \\
\hline Petrol & $\begin{array}{l}1.221^{\star \star} \\
(2.237)\end{array}$ & $\begin{array}{l}0.344 \\
(0.753)\end{array}$ & $\begin{array}{l}0.097 \\
(0.346)\end{array}$ & $\begin{array}{l}-0.621^{*} \\
(-1.897)\end{array}$ & $\begin{array}{l}-0.375^{\star \star} \\
(-2.150)\end{array}$ & $\begin{array}{l}-0.002 \\
(-0.009)\end{array}$ & $\begin{array}{l}0.372 \\
(1.391)\end{array}$ \\
\hline Kerosene & $\begin{array}{l}13.413^{\star \star} \\
(2.742)\end{array}$ & $\begin{array}{l}6.257^{*} \\
(1.526)\end{array}$ & $\begin{array}{l}-1.178 \\
(-0.470)\end{array}$ & $\begin{array}{l}-6.496 * \star \\
(-2.213)\end{array}$ & $\begin{array}{l}-2.470^{*} \\
(-1.578)\end{array}$ & $\begin{array}{l}-2.252 \\
(-1.321)\end{array}$ & $\begin{array}{l}-3.674^{*} \\
(-1.534)\end{array}$ \\
\hline Diesel & $\begin{array}{l}-1.766^{\star \star} \\
(-2.452)\end{array}$ & $\begin{array}{l}-0.505 \\
(-0.837)\end{array}$ & $\begin{array}{l}-0.194 \\
(-0.527)\end{array}$ & $\begin{array}{l}0.724 \\
(1.676)\end{array}$ & $\begin{array}{l}0.586^{*} \\
(2.544)\end{array}$ & $\begin{array}{l}0.167 \\
(0.664)\end{array}$ & $\begin{array}{l}1.716^{* \star \star} \\
(4.864)\end{array}$ \\
\hline Fuel oil & $\begin{array}{l}1.575 \\
(0.633)\end{array}$ & $\begin{array}{l}0.357 \\
(0.171)\end{array}$ & $\begin{array}{l}2.013^{*} \\
(1.580)\end{array}$ & $\begin{array}{l}-0.175 \\
(-0.117)\end{array}$ & $\begin{array}{l}-2.361^{\star \star \star} \\
(-2.968)\end{array}$ & $\begin{array}{l}-0.446 \\
(-0.514)\end{array}$ & $\begin{array}{l}0.422 \\
(0.346)\end{array}$ \\
\hline Aviation & $\begin{array}{l}-0.869 \\
(-0.640)\end{array}$ & $\begin{array}{l}-0.519 \\
(-0.457)\end{array}$ & $\begin{array}{l}-0.410 \\
(-0.589)\end{array}$ & $\begin{array}{l}-0.142 \\
(-0.174)\end{array}$ & $\begin{array}{l}1.994^{\star * *} \\
(4.595)\end{array}$ & $\begin{array}{l}0.165 \\
(0.347)\end{array}$ & $\begin{array}{l}0.679 \\
(1.019)\end{array}$ \\
\hline LPG & $\begin{array}{l}-3.192 \\
(-0.873)\end{array}$ & $\begin{array}{l}-1.237 \\
(-0.404)\end{array}$ & $\begin{array}{l}-3.897^{\star \star} \\
(-2.083)\end{array}$ & $\begin{array}{l}1.409 \\
(0.642)\end{array}$ & $\begin{array}{l}3.551^{\star \star \star} \\
(3.037)\end{array}$ & $\begin{array}{l}0.863 \\
(0.677)\end{array}$ & $\begin{array}{l}3.095^{\star} \\
(1.727)\end{array}$ \\
\hline
\end{tabular}

Note: Price of aviation fuel is not available so price of the joint product asphalt is included instead to test for the cross effects on other petroleum products. $t$-statistics are provided in the parentheses.

An alternative econometric approach of estimating energy elasticities is discussed in Maddala, Trost, Li and Joutz (1997). They argue that the general procedure used in the analysis of panel data commonly known as the fixed-effects and random-effects model, based on the homogeneity of the slope coefficient, might not be convincing while the cross-section approach, based on complete heterogeneity assumption, is too extreme and might yield bad results. They therefore propose an alternative framework using a Bayesian approach to solve this problem that will lead to a shrinkage estimator that will 
reduce the ordinary least squares (OLS) estimator toward the estimator of overall mean. They claim that a shrinkage estimator gives much more reasonable results based on having used it to estimate the short-run and long-run elasticities of energy demand for 49 U.S. states, using 21 years of data.

\section{Review on Thailand's Petroleum Demand by Economic Sectors}

\section{IV.1 Economic Growth}

Thailand enjoyed high economic growth during the 1980s, with a growth rate of about 7.8 percent per year. The real GDP increased substantially from about 0.9 billion baht in 1980 to 1.7 billion baht in 1989, almost doubling within one decade. Unfortunately, the 1997 financial crisis hit the economy severely. Economic growth declined sharply into a deep economic recession, with a negative growth rate of -1.4 and -10.4 percent in 1997 and 1998, respectively. However, the economy recovered quickly and the average growth rate rebounded to 4 percent per year at the end of the 1990s. From 2000 to 2007, the economy has grown continuously with a moderate growth rate of 3.5 percent. Throughout the past decades, the population has increased at a steady rate of 1.1 percent per year while the per capita income has increased sharply, growing three-fold from 19,721 baht in 1980 to 67,333 baht in 2007.

Even though Thailand does not abound with oil and mineral resources, it is abundant in other natural resources, such as timber and agricultural products, which helped propel its growth in the past decades. Almost fifty years ago, Thailand was a primitive economy whose main output was agricultural products, particularly rice. As a result, the agricultural sector accounted for about 30 percent of the GDP while industrial sector took only 15 percent share of the GDP. Now the picture has been reversed as the country becomes more developed. The share of the agricultural sector has dropped continuously to about 10 percent while the share of industrial sector has increased to 46 between 2000 and 2007. In the same way, the service sector, including transportation and residential and commercial sector, has maintained its important role in the economy and contributes more than 40 percent of the GDP.

Table 2: Output Growth and the Structure of GDP

\begin{tabular}{llll}
\hline \hline & 1980s & 1990s & 2000-2007 \\
\hline Economic Growth* (\%) & 7.8 & 4.0 & 3.5 \\
Real GDP per capita* (Baht) & 23,703 & 44,218 & 58,422 \\
& & & \\
Share of domestic product generated by (\%) & 10 & 10 \\
Agricultural Sector & 17 & 42 & 46 \\
Industrial Sector & 34 & 47 & 44 \\
Service Sector & 49 & & \\
\hline
\end{tabular}

Source: National Economic and Social Development Board

* 10-year average

\section{IV.2 Energy Demand}

With the rapid economic and steady population growth during the past decades, Thailand's overall energy demand has grown substantially at an average of 7.0 percent per year. Thailand's total energy demand in 1980 was 9,056 thousand tons of crude oil 
equivalent (ktoe) but has increased six-fold to 54,405 ktoe in 2007. The per capita energy consumption has increased over the past 27 years by 5.7 percent from 0.2 ktoe in 1980 to 0.9 ktoe in 2007.

Figure 1: Comparative Trend in Thailand's GDP and Total Final Energy Consumption

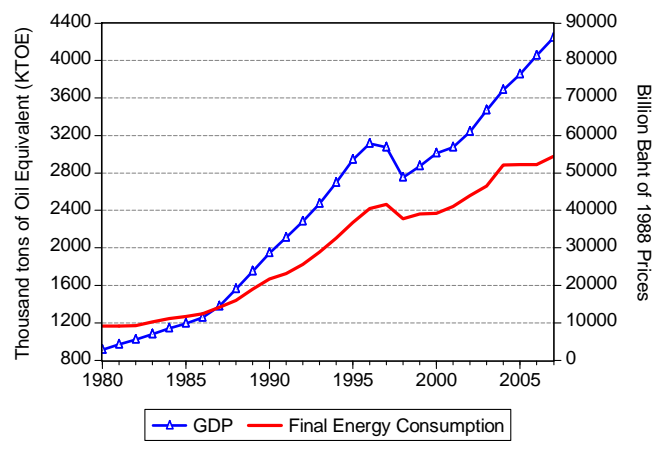

Figure 1 shows the trend in GDP and total energy consumption for Thailand since 1980. The trend clearly indicates that there is a strong linkage between energy and the economy. It may be noticed that since 1987 the discrepancy between the two curves has become wider. This may be due partly to the more efficient use of energy in the economy and greater productivity resulting from technology advancement especially in the industrial and service sectors.

Figure 2: Comparison of the growth rate of GDP, energy consumption and population

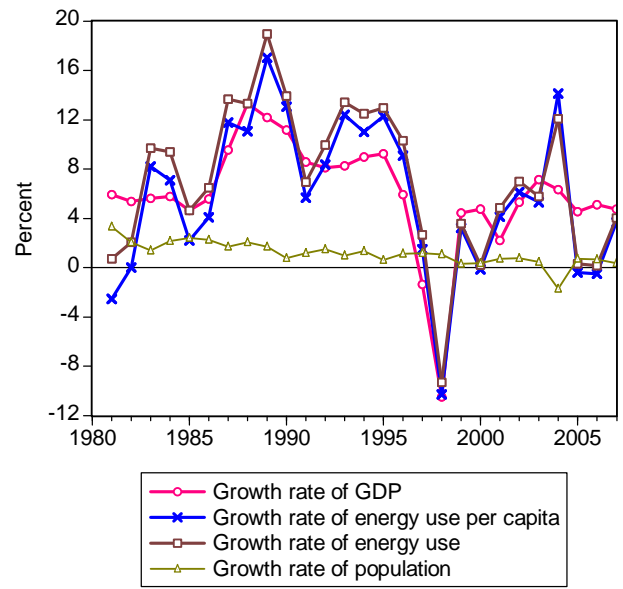

Figure 2 also emphasizes the same relationship between the growth rate of total energy use and per capita energy use, showing that they are closely related to the macroeconomic performance especially in the period of recession when energy use dropped at almost the same rate as the economic growth rate. However, population growth seems to have little effect on energy consumption growth. 
Table 3: Final Energy Consumption and GDP contribution by sector (Unit: percent)

\begin{tabular}{|c|c|c|c|c|c|}
\hline & $1986-1990$ & 1991-1995 & $1996-2000$ & 2001-2005 & $\begin{array}{r}\text { Average } \\
1986-2005 \\
\end{array}$ \\
\hline \multicolumn{6}{|c|}{ Share of Final Energy Consumption by Sector ${ }^{1}$ : } \\
\hline Transportation & 37 & 38 & 39 & 37 & 38 \\
\hline Industry & 28 & 32 & 34 & 36 & 32 \\
\hline Residential \& Commercial & 30 & 24 & 21 & 21 & 24 \\
\hline Agriculture & 5 & 6 & 6 & 6 & 6 \\
\hline \multicolumn{6}{|c|}{ GDP Contribution by Sector': } \\
\hline Transportation & 7 & 8 & 9 & 10 & 9 \\
\hline Industry & 37 & 42 & 43 & 46 & 42 \\
\hline Residential \& Commercial & 42 & 40 & 38 & 34 & 38 \\
\hline Agriculture & 14 & 11 & 10 & 10 & 11 \\
\hline
\end{tabular}

Table 3 shows that in the past twenty years, the transportation sector has used the largest share, 38 percent, of the total energy consumption. While this sector's share has continued at such a high level since 1986, its GDP contribution to the economy has been comparatively small and remained stable at only about 9 percent of the GDP. The second and the third major energy users are the industrial and residential and commercial sectors. They account for about 32 and 24 percent of the total energy consumption; however, they contribute significantly to the overall GDP with about 42 and 38 percent of the total GDP respectively. Agriculture uses the smallest share of energy, consuming only about 11 percent but its GDP contribution is as large as that of transportation sector.

Figure 3: Composition of Thailand's Final Energy Demand

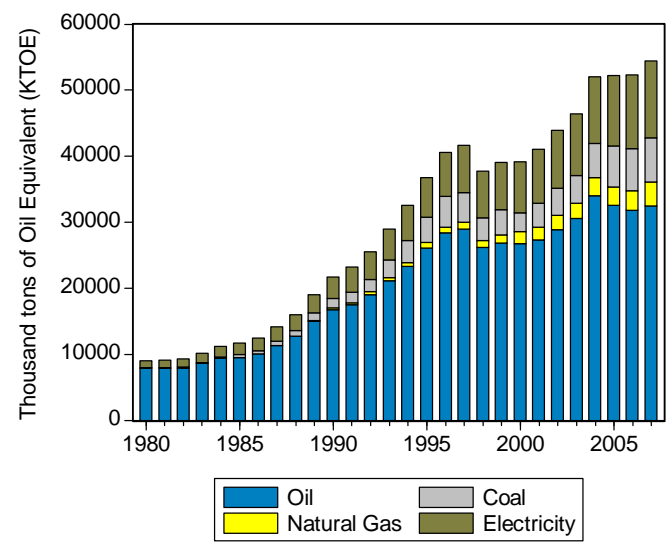

It can be seen from figure 3 that fossil fuels, especially oil and natural gas, have taken a dominant role, accounting for approximately 76 percent of the country's total energy consumption, while coal and electricity have taken only 7 and 17 percent share respectively. In fact oil has lowered its share in the final energy mix significantly since 1980 as a result of the introduction of new technologies to replace oil with natural gas and coal in heat and power generation. Moreover, since 2000 oil prices have risen dramatically and this has raised concerns about heavy oil use in the economy. Therefore, many consumers have switched from oil to other cheaper alternative fuels such as natural gas and biofuels (ethanol and biodiesel), particularly in the transport sector. 


\section{IV.3 Demand for Petroleum Products}

Oil can be classified into seven major petroleum products namely, liquefied petroleum gas (LPG), kerosene (jet fuel), premium gasoline, regular gasoline, high-speed diesel (HSD), low-speed diesel (LSD), and fuel oil. Basically, when petroleum products are burned to generate energy, they can be used for a variety of purposes, including propelling a vehicle, as would be the case with gasoline, kerosene (or jet fuel), diesel fuel, and LPG; producing the heat and steam for industry as with fuel oil or LPG; generating power by spinning a turbine directly or creating steam to spin a turbine as with diesel fuel and fuel oil. Moreover, oil products can also be used as a raw material or socalled feedstock in the petrochemical industry. As can be seen from table 4, about 60 percent of petroleum products are used in the transportation sector while the remaining 40 percent is used in agriculture, mining, manufacturing, electricity generation, construction, and the residential and commercial sectors. Therefore, overall there are seven major consuming sectors and seven types of petroleum products.

Table 4: Share of Oil Consumption by sector (Unit: percent)

\begin{tabular}{lrrrr}
\hline \hline Economic Sector & $\mathbf{1 9 8 1 - 1 9 9 0}$ & $\mathbf{1 9 9 1 - 2 0 0 0}$ & $\mathbf{2 0 0 0 - 2 0 0 6}$ & $\begin{array}{r}\text { Average } \\
\mathbf{1 9 8 1 - 2 0 0 6}\end{array}$ \\
\hline Agriculture & & & 9.6 & 8.6 \\
Mining & 10.2 & 0.1 & 0.1 & 0.2 \\
Manufacturing & 0.5 & 12.6 & 11.9 & 12.5 \\
Electricity & 13.0 & 13.3 & 3.5 & 9.1 \\
Construction & 10.4 & 0.8 & 0.4 & 0.7 \\
Residential \& Commercial & 0.9 & 6.0 & 7.4 & 6.3 \\
Transportation & 5.6 & 60.9 & 67.1 & 62.0 \\
\hline Source: Energy Policy and Planning Office & 58.0 & & &
\end{tabular}

Source: Energy Policy and Planning Office

Figure 4: Oil Consumption by Sectors

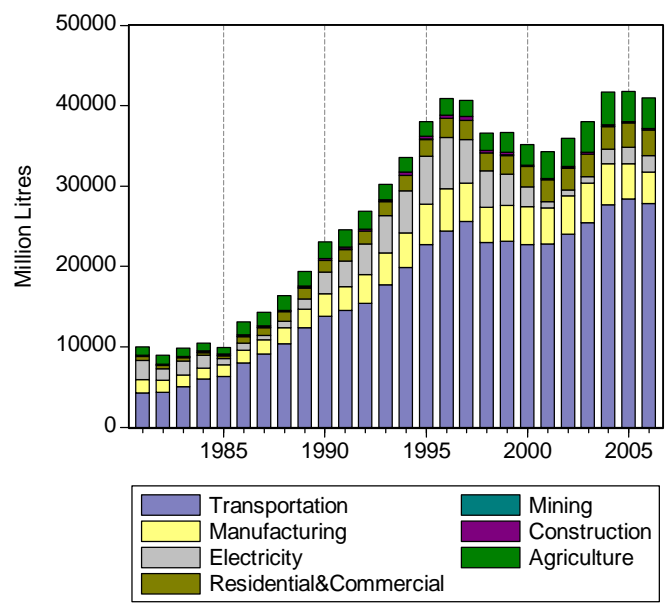

Figure 4 shows that the transportation sector always takes the largest share of the national oil consumption followed by manufacturing, electricity, residential \& commercial, and agricultural sectors. Transportation is the most important component of oil demand because given the current vehicle technology; it is still difficult to find substitutes for oil. While there is promising ongoing alternative energy research involving fuel cells, gasohol (blending ethanol with gasoline), biodiesel and photovoltaic cells, these 
technologies are still expensive and feasible only at times of high oil prices. Theoretically speaking, the demand for oil in the transportation sector is rather inelastic.

Figure 5: Oil Consumption by Petroleum Products

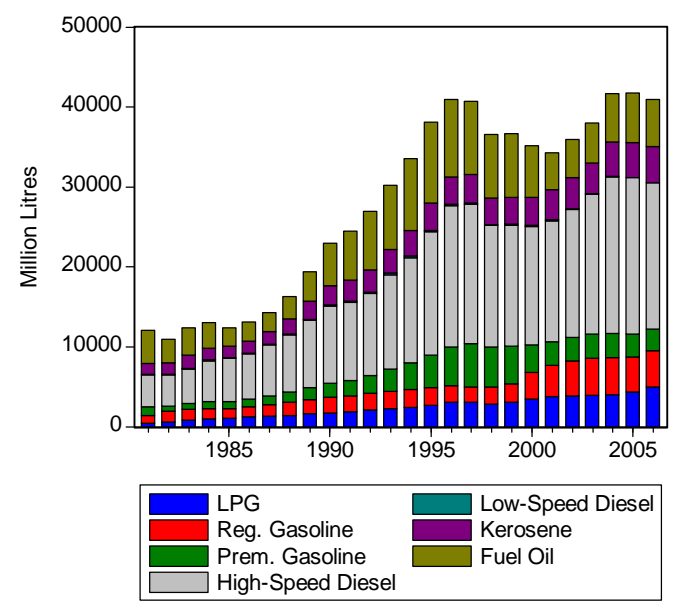

In terms of petroleum products, figure 5 shows that high-speed diesel takes the largest share or about 42 percent of the total petroleum consumption followed by fuel oil and kerosene/jet fuel with an average share of 21 and 11 percent of total petroleum use respectively. Premium and regular gasoline take about almost the same proportion at 9 percent of total petroleum use. The LPG share has increased gradually and averaged at about 8 percent. Low-speed diesel takes the smallest share at only about 0.5 percent of total petroleum use.

Table 5: Share of Oil Consumption by product and by sector during 1981-2006: (Unit: percent)

\begin{tabular}{|c|c|c|c|c|c|c|c|}
\hline Economic Sector & LPG & $\begin{array}{r}\text { Kerosenel } \\
\text { Jet Fuel }\end{array}$ & $\begin{array}{l}\text { Premium } \\
\text { Gasoline }\end{array}$ & $\begin{array}{r}\text { Regular } \\
\text { Gasoline }\end{array}$ & $\begin{array}{c}\text { High- } \\
\text { Speed } \\
\text { Diesel }\end{array}$ & $\begin{array}{l}\text { Low- } \\
\text { Speed } \\
\text { Diesel }\end{array}$ & Fuel Oil \\
\hline 1. Agriculture & 0.2 & 0 & 0.1 & 2.6 & 18.7 & 0.9 & 0.1 \\
\hline 2. Mining & 0 & 0.0 & 0.0 & 0.0 & 0.3 & 0.6 & 0.2 \\
\hline 3. Manufacturing & 16.8 & 1.5 & 1.0 & 0.6 & 4.1 & 21.8 & 43.4 \\
\hline 4. Electricity & - & - & - & - & 1.7 & - & 43.4 \\
\hline 5. Construction & - & 0 & 0 & 0.1 & 1.4 & 0.1 & 0.6 \\
\hline 6. Residential \& Commercial & 69.6 & 2.8 & 0 & 0 & 0.0 & 1.1 & 0.4 \\
\hline 7. Transportation & 13.0 & 94.8 & 98.8 & 96.4 & 73.7 & 74.8 & 11.8 \\
\hline Total & 100.0 & 100.0 & 100.0 & 100.0 & 100.0 & 100.0 & 100.0 \\
\hline
\end{tabular}

Source: 1. Energy Policy and Planning Office and 2. Department of Alternative Energy Development and Efficiency

Note: Data shown as " 0 " mean the value is less than 0.05

Table 5 shows the utilization of each petroleum product across economic sectors. LPG, known as cooking gas, is used mainly in residential and commercial activities. Kerosene/ jet fuel is used heavily as aviation fuel for both military and commercial flights. Premium and regular gasoline are used almost exclusively for motor vehicles. Highspeed diesel, which contains less sulfur and produces higher energy than other types of diesel, is mainly used for pick-up trucks and mass transit. The low-speed diesel, which has higher sulfur content, is used primarily in the manufacturing and transportation sectors. Fuel oil is used widely in various industries and for power generation by the Electricity Generating Authority of Thailand (EGAT). 


\section{Data}

The data used in this study cover seven major economic sectors and seven primary petroleum products between 1981 and 2007 in Thailand. The data of annual consumption of petroleum products have been published annually in the Thailand Energy Situation Report prepared by the Department of Alternative Energy Development and Efficiency (DEDE), Ministry of Energy. Originally, the primary data are collected by Ministry of Commerce, Ministry of Interior and some private sectors, then compiled and classified by DEDE according to petroleum products and consuming sectors.

The annual GDP (Gross Domestic Product), Capital Stock data are obtained from the National Economic and Social Development Board (NESDB), Office of the Prime Minister, while the annual Price Deflator and Labor employment data are from the Bank of Thailand (BOT). The Energy Policy and Planning Office (EPPO), Ministry of Energy, provided the data on petroleum prices, the basic background of overall energy consumption, production, energy policies, regulations and rules for past and present energy situations in Thailand.

This study considers seven major economic sectors in Thailand including:
1.) Agriculture
2.) Construction
3.) Electricity
4.) Manufacturing
5.) Mining
6.) Residential and Commercial
7.) Transportation

There are seven major petroleum products which are the focus of this study including:

1) Liquefied Petroleum Gas (LPG)

2) Kerosene (or Jet Fuel)

3) Premium Gasoline

4) Regular Gasoline

5) High-Speed Diesel (HSD)

6) Low-Speed Diesel (LSD)

7) Fuel Oil

Oil consumption in each economic sector in any year is the sum of petroleum products consumed by that sector in that year which is originally measured in million liters (Mlitres) for all products and then converted to be thousand tons of crude oil equivalent (ktoe) by using the conversion factor according to type of petroleum product as follows:
1) LPG:
1 Mlitres $=0.63014$ ktoe
2) Kerosene:
1 Mlitres $=0.8174$ ktoe
3) Gasoline:
1 Mlitres $=0.74507$ ktoe
4) Diesel:
1 Mlitres $=0.86198$ ktoe
5) Fuel Oil:
1 Mlitres $=0.94124$ ktoe 
The oil price in each sector is weighted average of real price of petroleum product which is in terms of Baht per tons of oil equivalent (Baht/toe). There are three steps of calculating the oil price for any economic sector. First, convert the current price of each petroleum product measured in Baht/liter to the real price by using the GDP deflator (1988 is the base year). Second, convert the real price of all petroleum products in Baht/liter to Baht/toe by using the conversion factor as mentioned earlier. Third, compute the weighted average of real oil price average in Baht/toe for each sector, which depends on the amount of petroleum products consumed in each sector.

Price of substitute energy for oil is a weighted average of real price of all kinds of energy use apart from oil in that sector which is measured in terms of Baht/toe. There are three types of substitute energy considered in this paper including electricity, coal and natural gas. There are three steps to compute the price of substitute energy. First, convert these prices faced by consumers in each sector into real term by using the GDP deflator (1988 is the base year). Second, convert the real price from its original unit to Baht/toe by using the conversion factor as follows:

$\begin{array}{ll}\text { Electricity: } & 1 \mathrm{kWh} \text { (Kilowatts-hours) }=0.00008521 \text { toe } \\ \text { Coal } & 1 \text { ton }=0.62419 \text { toe } \\ \text { Natural gas } & 1 \mathrm{MBtu}(\text { Million Btu) }=0.024927835 \text { toe }\end{array}$

We computed the weighted average of the real price of alternative energy according to the amount of alternative energy consumed in that sector.

The real GDP at 1988 prices in Millions of Baht for each economic sector is used as the real income level of that sector. The real Capital Stock at 1988 prices measured in Millions of Baht for each economic sector is used as a representation of capital input of that sector. The labor employment measured in thousands of people employed by the economic sector is used to represent the labor input of that sector.

\section{Methodology}

We consider two econometric approaches; they include: 1) Autoregressive Distributed Lag (ADL) Single Sector Approach and 2) Dynamic Panel Data Estimation Approach. The first yields the estimates of demand elasticities for each individual sector while the latter combines all sectors and estimates the demand elasticity for the economy as a whole. The details of each approach are provided as follows:

\section{VI.1 ADL Single Sector Approach}

The ADL modeling approach is based on general-to-specific approach advocated by Hendry (1986) and Hendry and Juselius (2000, 2001). The key objective of this approach is to use econometrics to discover the relationship of variables rather than to use it to validate economic theory. Therefore, it attempts to understand the characteristics of data properties from the sample. There are five basic steps of this approach including: 
1) Test for stationarity of the series

2) Estimate and solve for static long-run oil demand equation for all 7 sectors

3) Formulate the ECM (Error Correction Mechanism) terms

4) Incorporate the ECM terms into short-run dynamic model

5) Perform the model reduction process using Autometrics ${ }^{1}$.

The models that involve in each step are described as follows:

\section{VI.1.1 General ADL $(1,1)$ Model}

Oil consumption in each sector is specified to reflect the determinant factors and the economic development process. All economic variables are transformed to natural logarithms and thus the double log estimation equation for any sector can be written as:

$$
\begin{aligned}
& \text { LOIL }_{t}=\alpha_{0}+\alpha_{1} \text { LOIL }_{t-1}+\alpha_{2} \text { LPOIL }_{t}+\alpha_{3} \text { LPOIL }_{t-1}+\alpha_{4} \text { LPSUB }_{t}+\alpha_{5} \text { LPSUB }_{t-1} \\
& +\alpha_{6} L G D P_{t}+\alpha_{7} L G D P_{t-1}+\alpha_{8} L K_{t}+\alpha_{9} L K_{t-1}+\alpha_{10} L L_{t}+\alpha_{11} L L_{t-1}+u_{t}
\end{aligned}
$$

where $\mathrm{LOIL}_{t}$ is the quantity of oil consumption in thousand tons of oil equivalent (ktoe), $L_{P O I L}$ is the weighted real price of all petroleum products used by that sector in baht per toe, $\operatorname{LPSUB}_{t}$ is the weighted real price of substitute energy available in that sector in baht per toe, $L G D P_{t}$ is the real income generated by that sector in millions of baht using 1988 prices, $L K_{t}$ is the real capital stock in millions of baht using 1988 prices and $L L_{t}$ is labor employment in thousands.

\section{VI.1.2 Long-run Representation - derived from ADL}

The long-run solutions can be obtained by using the fact that when the dependent variables and independent variables are both nonstationary i.e. I(1), yet the linear combination of these variables is stationary i.e. I(0) then oil consumption and other explanatory variables are said to be cointegrated as suggested by numerous literature for example by Engle and Granger (1987) and Hendry (1986). This cointegration property has removed the unit roots and it is considered as the long-run relationship. Therefore, the deviation from the long-run equilibrium of oil consumption called Error Correction Mechanism (ECM) term can be derived and is given by:

$$
E C M_{t}=L O I L_{t}-\gamma_{1} L G D P_{t}-\gamma_{2} L P O I L_{t}-\gamma_{3} L P S U B_{t}-\gamma_{4} L K_{t}-\gamma_{5} L L_{t}
$$

If the variables are all stationary, the long-run solution is obtained simply from the rational distributed lag. In the ADL(1,1) case, the ECM is present if the coefficient on the

\footnotetext{
${ }^{1}$ Autometrics is general-to-specific algorithm proposed by Hendry and Krolzig (2001) consisting of five steps i.e. 1) Specification of General Unrestricted Model, 2) Test for misspecification, 3) Elimination of irrelevant variables, 4) Test for congruency and 5) Evaluate the terminal model. The key idea of this algorithm is that it eliminates irrelevant variables from the general model and retains only meaningful variables in the final model.
} 
lagged dependent variable is negative. This coefficient estimate is used to normalize the coefficients for the remaining explanatory variables.

\section{VI.1.3 Short-run ECM (Error Correction) Model}

The error correction model is specified in the first differences, which are stationary, to represent the short-run movements in the variables together with the lag of ECM term representing the deviation from the long-run equilibrium in the previous period. When the ECM term is incorporated into the model, both long-run and short-run relations are taken into account simultaneously and thus the dynamics of oil consumption in each sector can be captured.

$$
\begin{aligned}
& \Delta L O I L_{t}=\beta_{0}+\beta_{1} \Delta L O \text { IL }_{t-1}+\beta_{2} \Delta L P O I L_{t}+\beta_{3} \Delta L P O I L_{t-1}+\beta_{4} \Delta L P S U B_{t}+\beta_{5} \Delta L P S U B_{t-1} \\
& +\beta_{6} \Delta L G D P_{t}+\beta_{7} \Delta L G D P_{t-1}+\beta_{8} \Delta L K_{t}+\beta_{9} \Delta L K_{t-1}+\beta_{10} \Delta L L_{t}+\beta_{11} \Delta L L_{t-1}+\beta_{12} E C M_{t-1}+e_{t}
\end{aligned}
$$

Since the first difference model is stationary, estimation and statistical inference can be conducted using standard statistical approach. Once the ECM model was estimated, the following step is to use Autometrics to perform model reduction to obtain the final model which includes only relevant variables in explaining the oil consumption behavior in each economic sector.

\section{VI.2 Dynamic Panel Data Approach}

The second approach estimates short-run and long-run oil demand elasticities for Thailand using dynamic panel data methods. As discussed earlier, Frazen and Sterner (1995) use the time-series and cross-section data to estimate long-run gasoline demand elasticities for OECD countries between 1960 and 1988. We modify their model to the seven economic sectors. Dahl and Kurtubi (2001) estimate short-run and long-run demand elasticities of six oil products in Indonesia using an error correction model, but their approach is based on the time-series approach rather than panel data approach.

Hoa (1992) studied demand elasticities for six petroleum products in Thailand during the period 1974 to1987. His results are likely to be the most relevant and will be compared with our results. However, our model is more general, because the economic development process variables representing by the capital accumulation and labor employment in each sector are also taken into account. The regression model is the log linear model which can be written as follows:

\section{The Static Model:}

$L O I L_{i t}=\beta_{0}+\beta_{1} L P O I L_{i t}+\beta_{2} L P E L E_{i t}+\beta_{3} L G D P_{i t}+\beta_{4} L K_{i t}+\beta_{5} L L_{i t}+e_{i t}$

\section{The Dynamic Model:}

$$
L O I L_{i t}=\beta_{0}+\lambda L O I L_{i t-1}+\beta_{1} L P O I L_{i t}+\beta_{2} L P E L E_{i t}+\beta_{3} L G D P_{i t}+\beta_{4} L K_{i t}+\beta_{5} L L_{i t}+e_{i t}
$$

where $i=1, \ldots, 7$ represents economic sector and $t=1981, \ldots, 2007$ represents periods of the study, $\operatorname{LOIL}_{i t}$ is the quantity of oil consumption in thousand tons of oil equivalent (ktoe), 
$L_{P O I L}$ it the weighted real price of all petroleum products used by that sector in baht per toe, $L P E L E_{i t}$ is the real price of electricity used as a proxy of energy substitute in baht per toe, $L G D P_{i t}$ is the real income generated by that sector in millions of baht at 1988 prices, $L K_{i t}$ is the real capital stock in millions of baht at 1988 prices and $L L_{i t}$ is labor employment in thousand heads.

\section{VI.2.1 Estimation Method}

Since the dynamic panel data will encounter the problem of an inconsistent estimator, the GMM (Generalized Method of Moments) estimation of the dynamic Panel-Data model by Arellano and Bond (1991) will be applied to resolve the problem. In the context of this study, a simple balanced-panel model where there is only one lag of dependent variable on the right hand side of the equation is given by

$$
L O I L_{i t}=\beta_{0}+\lambda L O I L_{i t-1}+\beta_{1} L P O I L_{i t}+\beta_{2} L P E L E_{i t}+\beta_{3} L G D P_{i t}+\beta_{4} L K_{i t}+\beta_{5} L L_{i t}+e_{i t}
$$

After first differencing the above equation, we have

$$
\Delta L O I L_{i t}=\lambda_{1} \Delta L O I L_{i t-1}+\lambda_{2} \Delta L P O I L_{i t}+\lambda_{3} \Delta L P E L E_{i t}+\lambda_{4} \Delta L G D P_{i t}+\lambda_{5} \Delta L K_{i t}+\lambda_{6} \Delta L L_{i t}+\Delta u_{i t}
$$

With the first differencing equation, an instrument matrix can be constructed and the parameters of interest can be estimated subsequently. The matrix of instrumental variables for sector $i, Z_{i}$, is composed of the elements of $L O I L_{i t}$ and $\Delta x_{i t}$ where $X_{i t}=\left(L O I L_{i t-1}, L P O I L_{i t}, L P E L E_{i t}, L G D P_{i t}, L K_{i t}, L L_{i t}\right)$. This matrix can be written as:

$$
Z_{i}=\left(\begin{array}{cccccccccccc}
\text { LOIL }_{i 1} & 0 & 0 & 0 & 0 & 0 & 0 & \ldots & 0 & 0 & 0 & \Delta x_{i 3} \\
0 & \text { LOIL }_{i 1} & \text { LOIL }_{i 2} & 0 & 0 & 0 & 0 & \ldots & 0 & 0 & 0 & \Delta x_{i 4} \\
0 & 0 & 0 & \text { LOIL }_{i 1} & \text { LOIL }_{i 2} & \text { LOIL }_{i 3} & 0 & \ldots & & & & \\
0 & 0 & 0 & 0 & 0 & 0 & \ldots & 0 & \text { LOIL }_{i 1} & \ldots & \text { LOIL }_{i T-1} & \Delta x_{i T}
\end{array}\right)
$$

\section{VI.2.2 Model Choices}

In our study, the 1-step GMM estimation method has been used. The estimated results are varied depending on choice of instruments and choice of dummies that are selected. For the choice of instruments, the GMM level of oil consumption and constant dummies have been applied. Several combinations between including and excluding "group dummies" have been tested. Since including the group dummies would allow the model to take into account effects on oil consumption from other sources which might not be captured by the model and these effects are supposed to be different from sector to sector. The choice of whether or not to include the price of substitute energy is another factor of consideration. Although the electricity price might be the best available proxy of energy substitute, the rather stable prices of electricity during the period of study might affect the accuracy of the estimation results. 


\section{Empirical Results}

In this section, the results of the ADL single sector approach and the Dynamic Panel Data approach will be discussed. The analysis starts from a general model of oil consumption incorporating both demand and supply determinants. Our general model includes the standard demand variables like own-price and income and production function determinants like capital, labor, and the price of substitutes. If capital and labor do not provide explanatory power, then we would interpret the model as one for consumer demand. Otherwise, we consider the model as explaining the demand for oil in a production function, with income/output representing scale effects.

\section{VII.1 ADL Single Sector Approach}

\section{VII.1.1 Unit Root Tests}

The unit root tests used in this section is the Augmented Dickey-Fuller tests (ADF). The tests have been conducted based on two regression specifications i.e. 1) with constant term and 2) with constant plus trend term. The results of the ADF tests are reported in tables 6 - 9. The test in levels or I(1) are reported in Tables 6 and 8; the first include a constant and the second includes a constant and trend. Tables 7 and 9 report the results of unit root checking on the first difference series; the level is I(2). The null hypothesis of the $\mathrm{ADF}$ test is the series follows a unit root. If the null cannot be rejected, we conclude there is a unit root and the series is nonstationary.

As can be seen from table 6 and 8, the results indicate that there is evidence to support that the series are nonstationary. Even though the results in table 6 show that the null hypothesis are rejected for GDP (in manufacturing), K (in manufacturing) and L (in mining) when the trend is not included, the results in table 8 turn out to be different to support the presence of unit root in those variables when constant and trend are included. Likewise, the results in table 8 show that the null hypothesis can be rejected for POIL (in electricity), GDP (in agriculture) and L (in construction), but it cannot be rejected when the trend is not included. Thus we find evidence of nonstationarity in 37-40 tests with both specifications. The three cases where the null is rejected are different in the two tables. Based on graphical results, we tend to believe these rejections may be due to the power of the test.

The ADF tests for the first differences are presented in table 7 and 9. We reject the null hypothesis of unit root in most cases across all sectors except in the case of K. Although the t-statistics for $\mathrm{K}$ might not be statistically significant, the coefficients of the lag one period of $\mathrm{K}$ in the ADF tests are numerically far from unity. Also, the idea that a slowly evolving real variable follows an I(2) process is counterintuitive. Thus, we conclude the variables in our analysis are I(1) series. 


\section{VII.1.2 Modeling the Long-run static relations}

The long-run relationship of oil demand is specified to reflect the economic determinants and development process in each sector. Table 10 presents the long-run relationship between oil consumption and the determinant factors including oil price, price of substitute energy, income, capital and labor. In all cases these explanatory variables are jointly significant except in mining sector in which the $\chi^{2}(5)$ statistic is fairly low at 0.53. Moreover, it appears that none of the variables in Mining sector is individually significant. Given the relatively small contribution of the Mining sector to oil consumption in the economy and the unfavorable outcomes from these statistical tests, we decide to drop Mining sector from our analysis and proceed to the next step with only six sectors. We discuss the long-run results in Table 10. We find interesting details across the explanatory variables and sectors.

\section{Price of Oil}

It appears the long-run oil price elasticity is inelastic in five of six sectors. As can be expected, the oil price is most inelastic in Transportation sector with the magnitude of only -0.17 followed by Electricity -0.23 , Agriculture -0.27 , Manufacturing -0.87 and Construction -0.91 . The most inelastic oil demand in the Transportation sector might be explained by the limited choices of fuels available in the Transportation sector. Even though the Thai government has promoted to use more natural gas known as NGV (natural gas for vehicle) and biofuels such as gasohol or biodiesel in the past 10 years, it did not help much to increase the impact of oil prices in this sector. The same situation also appears to have occurred in the Agriculture sector where farmers and fishermen still have limited choices of fuels and fuel using capital equipment. They are still exposed to oil price and quantity shocks. The electricity sector seems to be in a better position since it can switch to other cheaper fuels like natural gas, coal and hydro power as well as other renewable energy sources.

Oil consumption in the Manufacturing and Residential and Commercial sectors are more price elastic with the value of -0.87 and -1.03 , which implies that these two sectors are more flexible in adjusting their oil consumption when oil prices change. The main reason is that during the past 27 years, Manufacturing and Residential and Commercial sectors have been able to switch to other cheaper alternative energy choices. Manufacturing sector has switched to use more coal and natural gas and Residential and Commercial sector switched to use more electricity and less kerosene.

\section{Price of Substitute Energy}

The role of alternative energy in each sector is different depending on the sector's characteristics. This may explain the different signs of the estimates in various sectors. The positive sign of the estimate indicates that other forms of energy used by that sector seems to be a substitute for oil while the negative sign seems to indicate that alternative energy in that sector might be a complement rather than substitute. We find that alternative energy in Agriculture, Manufacturing and Residential and Commercial sector 
appear to be substitutes with the value of $0.21,0.74$ and 1.28 respectively. The reason is the same as what have been described earlier that energy substitutes are available in these sectors especially in Manufacturing and Residential and Commercial sector.

If we take a closer look on the Agricultural sector, despite the increased availability of electricity over time, it appears as though it is a complement. We interpret this to the limited choice of technology for fuel switching in the Agricultural sector. In the Manufacturing sector, the situation is slightly more flexible than the Agriculture sector since there are many types of energy can be used in this sector. This has been shown in the historical data in the past 27 years that oil consumption in the Manufacturing sector has dropped from about 40 percent to 10 percent of total energy use while electricity has risen from 14 percent to 21 percent, coal from 3 percent to 32 percent and natural gas from 0 percent to 10 percent of total energy use.

Although the electricity use in Residential and Commercial has risen rapidly over time and dominates the commercial energy consumption in this sector, the level of oil consumption has remained quite stable over time. This might explain why the elasticity of oil substitutes in residential sector is much greater than that of Agricultural and Manufacturing sector.

However, in the Electricity sector, alternative energy appears to be a complement rather than a substitute with the elasticity value of -0.61 . This is consistent with the current situation in Thailand's power generation sector where oil has been used as a complementary fuel with natural gas for the old power plants and for the peak power generation. Phumpradab et. al. (2009) report that the thermal power plants in Thailand use a fuel mix of 56 percent of natural gas and 44 percent of fuel oil by energy content. That may explain why the alternative choices of fuel are complementary in the Electricity sector.

\section{GDP}

As can be seen from table 10, GDP has a positive long-run impact on oil consumption in all sectors. The results show that an increase in GDP by 1 percent can cause oil consumption in the Electricity, Manufacturing, Residential and Commercial as well as Transportation sector to increase by $3.22,2.06,1.08$ and 0.76 percent respectively.

The impact of GDP on oil consumption is largest in the Electricity sector. One possible explanation is that as economy grows, electricity consumption has grown accordingly. This growing electricity demand has induced the power generators to expand their power plants especially coal-fired power plants which are considered the most cost effective. However, power generators have faced with many social and environmental protests from villagers and pro-environment group. Therefore, they could not build as many new coalbased power plants as expected. Their second-best option is to revamp the old power

generators using a fuel mix of natural gas and fuel oil. As a result, the oil consumption in the Electricity sector has increased accordingly with a strong effect from the GDP. 
Moreover, in the Manufacturing sector, the situation is the same as that of Electricity sector. The Manufacturing sector tends to consume more oil, electricity and coal during peak production periods. The greater use of electricity in manufacturing sector reinforces the peak power demand which is met by fuel oil using power plants. However, the greater use of coal by the Manufacturing sector tends to drive up the coal price in the domestic market and would induce the Electricity sector to use less coal but more oil, which will indirectly promote higher oil consumption in electricity sector.

In the Residential and Commercial sector, the higher income is associated with the expansion of urbanization, LPG (known as cooking gas) has therefore risen sharply throughout the period of study. As a result of the economic development and urbanization throughout the country, the Transportation sector has grown accordingly and thus oil use in the Transportation sector has increased substantially.

\section{Capital}

It appears that the elasticity of oil consumption with respect to capital turns out to be negative in all sectors except in the Agriculture sector with the value about unity. The positive value for the capital elasticity is associated with the agricultural development process which requires more oil consumption for irrigation and mechanization. However, the negative values in other sectors can be interpreted as the saving of oil consumption due to the technology advancement and the efficiency improvements in equipment and techniques of production.

The Thai government has attempted to promote energy efficiency policies for almost a decade. Our results may reflect some of the benefits from these policies. The Electricity sector and the Manufacturing sector seem to manifest this energy efficiency effect the most. The effects are -2.52 and -2.53 respectively. This can be explained by the fact that new machines were installed in the power plants and industry. These are designed to use more energy sources like coal, natural gas and renewable energy. Therefore, the more investment in new machines, the less oil will be consumed in that sector.

However, the oil saving effect is smallest in the Transportation sector with the magnitude of only - 0.16 . This can be understood clearly if we take a look back on the technology of automobiles during the past decade. The automobile industry does not pay much attention on producing energy-saving cars especially in the period of 1986-1998 when oil price was relatively cheap. The trend of technology in that time is geared towards the luxurious and speedy cars. Only in recent years, the high oil price period, have automakers become more alert to producing more fuel efficient cars, hybrid cars and alternative-energy cars. Although these technology options are not fully integrated into the markets, it can help reduce future fuel oil consumption in the Transportation sector.

\section{Labor}

The results are consistent and point out that in the long run the more labor employed in the sector the higher oil consumption will be. The results show that the impact of higher 
labor employment is largest in the Residential and Commercial sector with the magnitude 1.60 followed by the Manufacturing sector 1.56, the Construction sector is 1.47 and the Agriculture sector is 1.19. These results are not surprising because as greater labor is employed in these sectors the requirements equipment to perform the tasks would increase and that would lead to higher oil use.

The labor induced oil use effects are less in the Electricity sector and Transportation sector with the value less than unity, only 0.36 and 0.68 respectively. The explanation is that labor is not as critical in producing power in electricity sector. The employment of labor is driven by the capital stock and technical aspects to ensure that the system will run smoothly and safely.

In the Transportation sector, transporting goods and passengers are mostly operated by public sector and some private licensed operators. There are exact schedules and routine routes running all year round with a good control on the amount of oil use regularly. Therefore, the higher labor employment in Transportation sector tends to generate small effects on oil consumption.

The results in table 10 were used to formulate the error correction term for seven sectors as presented in table 11. The ECM term representing the deviation from the long-run equilibrium will be incorporated into the General Unrestricted Model (GUM) which will be discussed in the next part.

\section{VII.1.3 General-to-Specific Modeling Approach}

The long-run relationships among variables in each sector are obtained from the previous analysis. To model the demand for the oil for all sectors in a more comprehensive way, a short-run error correction model is used. The error correction framework models the variables of interest in differences and the coefficients on the differenced variables are interpreted as short-run elasticities. Under the ECM framework, the model includes an ECM term obtained from the long-run relationship representing the deviations in oil consumption from its long run equilibrium level. The estimated coefficient of the ECM measures the speed of adjustment. The greater the value the faster the adjustment process back to the long-run equilibrium will be.

The results of general model of short-run oil demand are presented in table 12. All variables are in terms of change in the natural logarithm i.e. the growth rate. The table can be read along the column corresponding to the sector of interest. The value in each cell represents the coefficient of the variables in each row. Basically, there are thirteen variables on the right hand side of the equation including the lag of the dependent variable, contemporaneous and lags of the explanatory variables, one lag of the ECM term and a constant term. The Construction and Transportation sectors have only eleven variables, because the price of substitute energy was not available. A summary of the residual diagnostic tests for each equation is reported in the lower panel of the table. These tests include AR 1-2 test, ARCH 1-1 test, Normality test and Reset test. The residual diagnostic, the one-step Chow test and the break point Chow test. 
The AR 1-2 test is the test for error autocorrelation from lags 1 to 2 which is based on the null hypothesis that there is no autocorrelation in error terms i.e. they are white noise. The results in the lower panel of table 12 suggest that the null cannot be rejected in all sectors, which means that the error terms are white noise in the model of all sectors.

The ARCH 1-1 test examined the error ARCH (Autoregressive Conditional Heteroscedasticity) from lags 1 to 1 . This is the joint test of the significance of lagged squared residuals in the regression of squared residuals on a constant and lagged squared residuals. Again, the results show that there is no statistical evidence of autocorrelation conditional on heteroscedasticity in the error terms in all sectors.

The Normality test checks the skewness and kurtosis of the residuals to ensure that they correspond to a normal distribution. The results show that there is no evidence to reject the null hypothesis that the distribution of errors is normal except in the case of Residential and Commercial sector. The last test is RESET test or (Regression Specification Test). This test is based on the null hypothesis of correct specification of the model functional form. We find that the null is rejected in the Agriculture and Mining sector. Results for the Mining sector are not reported since the model has poor statistical properties to begin with.

In the next step, the final parsimonious model of oil demand in each sector is presented in table 13. This parsimonious model was obtained from conducting the model reduction process by applying general-to-specific modeling algorithm known as Autometrics to the General Unrestricted Model (GUM) presented in table 12. The basic ideas of model reduction is that it eliminates irrelevant variables from the general model and retains only meaningful variables by employing statistical tests of significance and misspecification through residual diagnostics and evaluating the final models through encompassing tests as suggested by Hendry and Krolzig (2001). In this study, the significance level of 5 percent was chosen as a cut off point of irrelevant variables and the outlier detection is set at 1.0 percent.

The results in table 13 show that in the short run the effect of GDP on oil consumption is highly significant in Manufacturing, Residential and Commercial and Transportation sector. Only in Construction sector, the lag of GDP was found to be significant. Among these sectors, the short-run impact of GDP on oil consumption is largest in the Manufacturing sector with the magnitude of 1.58 followed by the Residential and Commercial sector and Transportation sector at 1.21 and 0.94 respectively.

The short-run oil price elasticity estimates suggest that the Transportation sector's oil demand is least sensitive to price with the magnitude of only -0.16 followed by Agriculture and Manufacturing sector with the elasticity value equal to -0.24 and -0.28 respectively. This result is similar to the long-run results found earlier in the long-run analysis. It is not a surprising result since oil is still the main or only energy used in Transportation sector and it is still difficult to find other energy substitutes even in the time of high oil prices in the short run. 
The short-run elasticity of oil consumption with respect to capital also shows the same sign as what had been found in the long run. The increase in capital in the short run appears to help lower oil consumption especially in Agriculture, Construction and Manufacturing sector. However, greater capital investment in the Electricity sector turns out to accelerate oil consumption in the short run.

Contrary to effect of capital on oil consumption, higher employment in the Agriculture, Construction, Manufacturing, and Transportation sectors have a positive impact on oil consumption in the short run. The impact of labor on oil consumption is greatest as indicated by the elasticity value of 1.45 in the Construction sector. This is due to the fact that labor is a primary input in the Construction sector. But in the Agriculture, Manufacturing and Transportation sector, the elasticity values are almost the same between around 0.3 and 0.5 . These findings are consistent with the results in the long run analysis except larger impacts from labor found in the long run.

Another interesting factor on oil consumption is price of substitute energy. It turns out from the statistical point of view price of substitute energy does not play a major role in influencing oil consumption in the short run. As can be seen in Table 14, in the specific model, price of substitute energy could not pass the criteria of the model reduction process and it has been dropped out in all sectors. One possible explanation is that in the short run variations in price of energy substitutes might not create a sufficient impact and lead to a significant change in the behavior of oil consumption in all sectors. Only when the price of energy substitutes has manifested a clear pattern in the long run will oil consumers be more confident to invest in new machines and equipment in order to switch from oil to other fuels. In other words, the trade off between the cost from investment in new technology and benefits from oil saving will be clearly realized only in the long run.

The error correction (ECM) term is significant in all sectors and has a negative sign with the size of less than unity except in Construction sector where the value of coefficient is almost equal to unity. The size of the ECM term indicates the speed of adjustment when the demand is above or below equilibrium. From table 14, Construction sector has the fastest speed of adjustment among all sectors. It means that if there is a deviation from the long-run equilibrium of oil consumption, the Construction sector tends to completely adjust within one year from a deviation from the long run equilibrium. If we compare the Manufacturing and Transportation sectors, they adjust their consumption by only 59 and 55 percent respectively from the deviation within the first year.

In general, the final parsimonious model in each sector has coefficients with expected signs and reasonable magnitude. The model for all sectors except the Mining sector performs well on the statistical points of view. The residual diagnostics indicate there is no evidence to support the presence of autocorrelation, conditional heteroscedasticity and normality as shown in Appendix A. See figures 6 - 12.

Furthermore, the one-step residuals lie within two standard error confidence bounds suggesting that there are no heavy outliers detected. The stability of the model is 
examined further by testing parameter constancy through recursive estimation. The results of the tests for all sectors are shown graphically in figures $6-12$. These figures show the one-step ahead and n-step-ahead Chow tests for individual equation of each sector on both general model and specific model. The one-step ahead considers oneperiod ahead of predictions from recursive estimation while the n-step-ahead Chow tests are a break point Chow tests. The test statistics are normalized on the critical value at 1 percent so that if the values exceed the unity bound, it suggests the rejections of the null hypothesis of structural breaks.

Overall, it appears there is evidence of structural breaks only in the Electricity and Mining sector. Models in the other sectors do not show any signs of structural breaks and it can be concluded that all equations satisfy parameter constancy condition at one percent significant level. In other words, the estimates are stable. Hence, the parsimonious model of oil consumption in six sectors can successfully capture the dynamics of oil consumption and it is also robust based on statistical grounds.

\section{VII.2 Dynamic Panel Data Approach}

The main distinction between the ADL single sector approach and the Dynamic Panel Data approach is that the estimated coefficients obtained from the dynamic panel data approach represents the elasticity value of oil consumption with respect to the corresponding variable across the whole economy not for any particular individual sector as discussed in the earlier part. Table 14A reports the estimated results and t-statistics of the dynamic panel data estimation approach for several model specifications. These model choices differ by the explanatory variables included and the treatment of group effects which capture the different characteristics among sectors.

There are six variables in the group effects including Group 2 (Construction), Group 3 (Electricity), Group 4 (Manufacturing), Group 5 (Mining), Group 6 (Residential and Commercial) and Group 7 (Transportation) because the Agriculture sector serves as the reference case. In addition, under the GMM framework, all variables shown in table 14A are in first difference of natural logarithm.

Column 1 contains the results of Model I in which there are only three explanatory variables: the lag of oil consumption, oil price and GDP. The different characteristics of oil consumption among sectors are not considered in Model I. It is the simplest case in the sense that it is the oil demand function depending on own price and income, it is used as a referenced model for comparing with other model specifications.

Model II as shown in column 2 of table 14 adds one additional variable, price of electricity to represent price of substitute energy. Likewise, Model III adds three new variables for comparison with Model I i.e. the price of electricity, capital and labor. Based on the results in Models II and III, it appears that price of substitute energy are not significant and does not help increase explanatory power of the model. Therefore, price of electricity has been dropped out from consideration. Model IV does not include price of electricity but include capital and labor. Model V is the same as Model IV but it takes 
into account the group effects which allow the intercept to adjust accordingly. Model VI is the same as Model V but it does not include capital and labor. As can be seen in table 14A, labor and capital are significant in Models III and IV, but when the group effects are included, only labor is significant but not capital. Considering the group effects in Model $\mathrm{V}$ and VI, the group effects turn out to be significant in all cases except Group 3 (Electricity) in Model V. The (de-meaned) consumption growth is not significant between Electricity and Agriculture.

The estimates for lagged oil consumption are significant in all of six model specifications and the values are quite close ranging between 0.62 and 0.76 . The oil price estimates in all specifications are negative and less than one around -0.26 and -0.40 , which indicate that the oil demand is rather inelastic in the short-run. The income estimates are positive and significant in all cases ranging from 0.13 to 0.31 . The capital elasticity is negative and significant in two of three cases with the value around -0.30 . The negative sign for the capital appears to be the same as those obtained from the ADL single sector approach. This suggests that additional capital stock tends to help save oil use in the economy which might be due to the technology improvement in machines and equipment. The response to labor is the reverse; it tends to accelerate oil use with the short-run elasticity values around 0.23 to 0.47 .

The results obtained in each specification were used to compute the short-run and longrun elasticity values as shown in table 15. As can be seen from the table, the short-run elasticity values with respect to all variables are less than the elasticity values in the longrun. These findings are consistent with the economic theory stating that consumption is more responsive to the change in economic variable in the long run rather than in the short run. In the context of this study, oil consumption behavior in the Thai economy seems to be consistent with standard economic predictions.

An increase in oil price by one percent in the short run can cause a reduction in oil consumption by about 0.26 to 0.40 percent. However, in the long run, an increase in oil price by one percent might lead to a decrease in oil consumption by 0.76 to 1.70 percent. When income increases by one percent in the short run oil consumption tend to increase by 0.13 to 0.31 percent while in the long run the effects are stronger at 0.34 to 0.92 percent. If the capital stock increases by one percent, it might help lower oil consumption by 0.3 percent in the short run and 1.19 percent in the long run. An increase in employment by one percent will cause higher oil consumption in the short run by about 0.20 to 0.47 percent and by about 0.74 to 1.24 percent in the long run.

The residual diagnostic test results are provided in table $14 \mathrm{~B}$. The results from the tests do not indicate any serious problems on these six models. The Wald (joint) tests showing the overall significance of all regressors are highly significant in all models. The Wald (dummy) tests including constant term are significant in four out of six cases. The Sargan test indicates that the null hypothesis of validity of the instruments cannot be rejected in all models. The residual diagnostic tests show that the error terms behave nicely and do not show any signs of autocorrelation either AR(1) or AR(2). Therefore, it can be concluded that the results from the dynamic panel data approach are fairly reliable 
and can provide us some clues of how much oil consumption of the whole economy would be affected by the change of each variable.

How do our results compare with previous research? There are several distinctions between this paper and Hoa (1992). Note, however that nearly 20 years have elapsed since that study. First, the own-price elasticities are positive and significant for several petroleum products in the first study. We find that the own price elasticities are negative in both the short run and long run. Further short-run elasticity is inelastic and rather elastic in the long-run. Second, the income elasticity is positive and highly significant in our paper in all sectors while in Hoa (1992), the income elasticity is negative for kerosene and positive in other petroleum products but only marginally significant. Third, in this paper, the magnitude of the income elasticity is less than unity in both short run and long run, but in the previous paper the magnitude is quite large between 0.4 and 3.1. Fourth, the previous paper does not distinguish between the short run and long run elasticities and did not consider the effect from price of energy substitute either. Our results are consistent with those found in the surveys by Dahl (1994) and in the study of Indonesia by Dahl and Kurtubi (2001).

\section{Conclusion}

We examine oil consumption behavior by sector in Thailand from 1980 to 2007. Oil consumption is the aggregate of seven petroleum products. The sectors are Agriculture, Construction, Electricity, Manufacturing, Mining, Residential \& Commercial, and Transportation.

Our analysis begins with a general model of oil consumption incorporating both demand and supply determinants. Our general model includes the standard demand variables like own-price and income and production function input determinants like capital, labor, and the price of substitutes. If capital and labor do not provide explanatory power, then we would interpret the model as one for consumer demand. Otherwise, we consider the model as explaining the demand for oil in a production function, with income/output representing scale effects.

We approach the econometric modeling from two perspectives: an autoregressive distributed lag perspective by sectors individually and a dynamic panel data approach. In both cases the model appears to explain oil consumption as an input demand in the production function. The dynamic panel data approach yielded estimates consistent with economic theory. The signs of the coefficients are correct and the long-run responses are larger than the short-run responses. The panel data approach combines information from all seven sectors and should be more efficient. However, it can be restrictive in that the elasticity estimates are the same across sectors. This may mask interesting issues when oil use is heterogeneous.

Several examples of the sector heterogeneity phenomenon are described below. The longrun labor elasticities are approximately unity in all sectors except in the Electricity sector where it is less than unity. Also, the short-run own price elasticity in the Electricity sector 
turned out to be positive. A possible explanation is that during peak demand periods and when energy prices increase, the sector has no other alternative generating capability and must use residual fuel legacy oil plants. We do not find significant short-run effects for the price of oil substitutes. Finally, we find evidence supporting that an increase in capital has a long-run negative impact on oil consumption in all sectors except in Agriculture sector. This result might be interpreted as greater capital accumulation in Agriculture sector leads to more demand for irrigation and mechanization in the economic development process. 


\section{References}

[1] Ahmadian, M., Chitnis, M. and Hunt, L.C. (2007). "Gasoline Demand, Pricing Policy and Social Welfare in Iran." SEEDS 117, February. Surrey Energy Economics Centre (SEEC).

[2] Arellano, M. and S. Bond. (1991). "Some tests of specification in panel data: Monte Carlo evidence and an application to employment equations." Review of Economic Studies, 58: pp.277-297

[3] Dahl, C. (1993). "A survey of oil demand elasticities for developing countries." OPEC Review, Winter, pp.399-410.

[4] Dahl, C. (1994a). "A survey of oil demand elasticities for developing countries." OPEC Review, Spring, pp.47-65.

[5] Dahl, C. (1994b). "A survey of energy demand elasticities for developing countries." The Journal of Energy and Development, Vol.18(1), pp.1-47.

[6] Dahl, C. and Kurtubi (2001). "Estimating oil product demand in Indonesia using a co integrating error correction model." OPEC Review, March, pp.1-25.

[7] Engle, R. and Granger, C.W.J. (1987). "Cointegration and error-correction: representation, estimation and testing." Econometrica 55(2), pp.251-276

[8] Frazen, Mikael and Sterner, Thomas (1995). "Long-run demand elasticities for gasoline." in Barker, T., Ekins, P., Johnstone, N. ed. Global Warming and Energy Demand. Routledge, London and New York.

[9] Hendry, D.F. (1986). "Econometric modeling with cointegrated variables: an overview." Oxford Bull. Econ. Stat. 48(3), pp 201-212

[10] Hendry, D.F. and Juselius, K. (2000). "Explaining cointegration analysis: Part I." Energy Journal Vol.21(1), pp 1-42

[11] Hendry, D.F. and Juselius, K. (2001). "Explaining cointegration analysis: Part II." Energy Journal Vol.22, pp 75-120

[12] Hoa, T.V. (1992). "A Multi-Equation Model of Energy Consumption in Thailand." International Journal of Energy Research, Vol.16, pp.381-385.

[13] Maddala, G.S., Trost, R.P., Li, H. and Joutz, F. (1997). "Estimation of Short-Run and Long-Run Elasticities of Energy Demand from Panel Data Using Shrinkage Estimators." Journal of Business \& Economic Statistics, Vol.15(1), Jan, pp. 90-100.

[14] Nicholson, W. (2005). "Microeconomic Theory: Basic Principles and Extensions." $9^{\text {th }}$ Edition (International Student Edition), Thomson (South-Western).

[15] Phumpradab, K., Gheewala, S.H. and Sagisaka, M. (2009). "Life cycle assessment of natural gas power plants in Thailand." The International Journal of Life Cycle Assessment, Vol.14(4), June 2009, pp. 354-363. Springer Berlin/ Heidelberg.

[16] Vita, G.D., Endresen, K. and Hunt, L. C. (2005). " An Empirical Analysis of Energy Demand in Namibia." SEEDS 110, July. Surrey Energy Economics Centre (SEEC). 
Modeling Oil Demand using the ADL Single Sector Approach (1981-2007)

Table 6: ADF Statistic Tests for a unit root in level with constant in ADF regression specifications

\begin{tabular}{|c|c|c|c|c|c|c|c|c|c|c|c|c|}
\hline \multirow[t]{3}{*}{ Sector } & \multicolumn{12}{|c|}{ Variable } \\
\hline & \multicolumn{2}{|c|}{ OIL } & \multicolumn{2}{|c|}{ POIL } & \multicolumn{2}{|c|}{ PSUB } & \multicolumn{2}{|c|}{ GDP } & \multicolumn{2}{|l|}{$\mathbf{K}$} & \multicolumn{2}{|l|}{$\mathbf{L}$} \\
\hline & $t$-statistics & Lag & $t$-statistics & Lag & $t$-statistics & Lag & $t$-statistics & Lag & $t$-statistics & Lag & $t$-statistics & Lag \\
\hline Agriculture & -0.65 & 0 & 0.08 & 0 & -1.56 & 0 & -0.76 & 2 & -0.95 & 1 & -1.28 & 0 \\
\hline Construction & -1.35 & 0 & 0.10 & 0 & - & - & -2.61 & 1 & -2.60 & 1 & -2.17 & 1 \\
\hline Electricity & -1.28 & 3 & 0.80 & 0 & -1.71 & 3 & -3.36 & 0 & -1.83 & 2 & -1.51 & 0 \\
\hline Manufacturing & -2.46 & 1 & 0.73 & 0 & -2.32 & 0 & $-3.07 *$ & 0 & $-4.08 * *$ & 2 & -2.36 & 0 \\
\hline Mining & -2.05 & 1 & 0.05 & 0 & -2.19 & 0 & -1.70 & 3 & -1.19 & 1 & $-4.55 * *$ & 0 \\
\hline Res. \& Com. & -2.34 & 2 & -2.49 & 1 & -2.46 & 2 & -1.86 & 1 & -1.51 & 0 & -1.83 & 0 \\
\hline Transport & -2.68 & 1 & 0.20 & 0 & - & - & -2.43 & 0 & -1.82 & 1 & -3.55 & 3 \\
\hline
\end{tabular}

Table 7: ADF Statistic Tests for a unit root in first difference with constant in ADF regression specifications

\begin{tabular}{|c|c|c|c|c|c|c|c|c|c|c|c|c|}
\hline \multirow[t]{3}{*}{ Sector } & \multicolumn{12}{|c|}{ Variable } \\
\hline & \multicolumn{2}{|c|}{ OIL } & \multicolumn{2}{|c|}{ POIL } & \multicolumn{2}{|c|}{ PSUB } & \multicolumn{2}{|c|}{ GDP } & \multicolumn{2}{|l|}{$\mathbf{K}$} & \multicolumn{2}{|l|}{$\mathbf{L}$} \\
\hline & $t$-statistics & Lag & $t$-statistics & Lag & $t$-statistics & Lag & $t$-statistics & Lag & $t$-statistics & Lag & $t$-statistics & Lag \\
\hline Agriculture & $-4.39 * *$ & 0 & $-3.79 * *$ & 0 & $-4.94 * *$ & 0 & $-6.47 * *$ & 1 & -2.02 & 0 & $-6.04 * *$ & 0 \\
\hline Construction & $-4.52 * *$ & 0 & $-3.85 * *$ & 0 & - & - & -2.20 & 0 & -1.38 & 0 & $-3.09 *$ & 1 \\
\hline Electricity & $-3.75 *$ & 2 & $-3.31 *$ & 0 & -2.64 & 0 & $-3.03 *$ & 0 & -1.53 & 1 & $-4.17 * *$ & 0 \\
\hline Manufacturing & -2.12 & 0 & $-3.43^{*}$ & 0 & $-3.72 *$ & 0 & $-3.30 *$ & 0 & -1.48 & 1 & $-4.13^{* *}$ & 0 \\
\hline Mining & $-7.47 * *$ & 0 & $-4.49 * *$ & 0 & $-4.41 * *$ & 0 & $-4.67 * *$ & 2 & -1.98 & 0 & $-4.86^{* *}$ & 2 \\
\hline Res. \& Com. & $-4.59 * *$ & 3 & -2.76 & 0 & $-3.22 *$ & 0 & -1.95 & 0 & -4.32 & 0 & $-4.12 * *$ & 0 \\
\hline Transport & -2.62 & 0 & $-3.40 *$ & 0 & - & - & $-3.17 *$ & 0 & -1.54 & 1 & $-5.60 * *$ & 0 \\
\hline
\end{tabular}

Table 8: ADF Statistic Testing for a unit root in level with constant and trend in ADF regression specifications

\begin{tabular}{|c|c|c|c|c|c|c|c|c|c|c|c|c|}
\hline \multirow[t]{3}{*}{ Sector } & \multicolumn{12}{|c|}{ Variable } \\
\hline & \multicolumn{2}{|c|}{ OIL } & \multicolumn{2}{|c|}{ POIL } & \multicolumn{2}{|c|}{ PSUB } & \multicolumn{2}{|c|}{ GDP } & \multicolumn{2}{|c|}{$\mathbf{K}$} & \multicolumn{2}{|l|}{$\mathbf{L}$} \\
\hline & $t$-statistics & Lag & $t$-statistics & Lag & $t$-statistics & Lag & $t$-statistics & Lag & $t$-statistics & Lag & $t$-statistics & Lag \\
\hline Agriculture & -1.96 & 0 & -0.28 & 2 & -1.67 & 0 & $-3.68^{*}$ & 0 & -3.23 & 3 & -2.22 & 0 \\
\hline Construction & -1.10 & 0 & -1.42 & 0 & - & - & -2.49 & 1 & -1.72 & 1 & $-4.78 * *$ & 0 \\
\hline Electricity & -0.96 & 3 & $-3.84 *$ & 0 & -1.52 & 0 & -1.03 & 0 & -0.09 & 2 & -1.78 & 0 \\
\hline Manufacturing & -0.67 & 1 & -3.15 & 0 & -1.11 & 0 & -2.21 & 1 & -3.60 & 1 & -1.52 & 0 \\
\hline Mining & -4.21 & 3 & -0.55 & 2 & -1.63 & 0 & -1.85 & 2 & -0.98 & 2 & -2.96 & 3 \\
\hline Res. \& Com. & -2.35 & 3 & -2.03 & 1 & -1.26 & 0 & -2.16 & 2 & -1.57 & 0 & -1.99 & 0 \\
\hline Transport & -1.85 & 1 & -0.91 & 2 & - & - & -1.26 & 0 & -1.92 & 2 & -0.92 & 3 \\
\hline
\end{tabular}

Table 9: ADF Statistic Testing for a unit root in first difference with constant and trend in ADF regression specifications

\begin{tabular}{|c|c|c|c|c|c|c|c|c|c|c|c|c|}
\hline \multirow[t]{3}{*}{ Sector } & \multicolumn{12}{|c|}{ Variable } \\
\hline & \multicolumn{2}{|c|}{ OIL } & \multicolumn{2}{|c|}{ POIL } & \multicolumn{2}{|c|}{ PSUB } & \multicolumn{2}{|c|}{ GDP } & \multicolumn{2}{|c|}{$\mathbf{K}$} & \multicolumn{2}{|l|}{$\mathbf{L}$} \\
\hline & $t$-statistics & Lag & $t$-statistics & Lag & $t$-statistics & Lag & $t$-statistics & Lag & $t$-statistics & Lag & $t$-statistics & Lag \\
\hline Agriculture & $-4.28 *$ & 0 & $-4.69 * *$ & 3 & $-5.74 * *$ & 0 & $-6.37 * *$ & 1 & -1.97 & 0 & $-5.89 * *$ & 0 \\
\hline Construction & $-4.75^{* *}$ & 0 & $-4.58 * *$ & 3 & - & - & -2.29 & 0 & -2.32 & 0 & -3.28 & 1 \\
\hline Electricity & $-4.10^{*}$ & 2 & $-4.27 *$ & 1 & -3.38 & 0 & $-3.38 *$ & 0 & -2.62 & 3 & $-4.13^{*}$ & 0 \\
\hline Manufacturing & -3.39 & 0 & $-5.39 * *$ & 0 & $-4.39 *$ & 0 & $-4.03^{*}$ & 0 & -3.56 & 1 & $-4.74 * *$ & 0 \\
\hline Mining & $-4.15^{*}$ & 3 & $-4.32 * *$ & 3 & $-5.44 * *$ & 0 & $-5.07 * *$ & 3 & -2.29 & 1 & $-6.09 * *$ & 2 \\
\hline Res. \& Com. & $-5.49 * *$ & 3 & -3.53 & 1 & $-4.62 * *$ & 0 & -2.11 & 0 & -4.30 & 0 & $-4.29 *$ & 0 \\
\hline Transport & -3.39 & 0 & -4.49 & 3 & - & - & $-3.68 *$ & 0 & -1.82 & 1 & $-4.18 *$ & 2 \\
\hline
\end{tabular}

Note: The ADF test covers the sample period from 1981 to 2007. All variables are in natural logarithms. A maximum of three lags is used to examine the autocorrelation of the residuals. Two types of ADF regression specifications are considered: 1 . with constant and 2 . with constant and trend. The critical values for $t$-tests at $5 \%$ are -3.00 and -3.63 , respectively and at $1 \%$ the values are -3.77 and -4.44 respectively. The rejection of the hypothesis of the presence of unit roots is denoted by * and $* *$ for $5 \%$ and $1 \%$ respectively. 
Modeling Oil Demand using the ADL Single Sector Approach (1981-2007)

Table 10: The static long-run equation for oil demand by sector

\begin{tabular}{|c|c|c|c|c|c|c|c|}
\hline Variable & Agriculture & Construction & Electricity & Manufacturing $\dagger$ & Mining & $\begin{array}{l}\text { Residential } \\
\text { \& Commercial }\end{array}$ & Transportation \\
\hline Constant & $\begin{array}{l}-22.89 * * * \\
(-3.27)\end{array}$ & $\begin{array}{l}10.36 \\
(1.09)\end{array}$ & $\begin{array}{l}9.09 \\
(0.60)\end{array}$ & $\begin{array}{l}-29.25 * * * \\
(-3.99)\end{array}$ & $\begin{array}{l}7.99 \\
(0.26)\end{array}$ & $\begin{array}{l}-17.16^{* *} \\
(-2.28)\end{array}$ & $\begin{array}{l}-0.39 \\
(-0.42)\end{array}$ \\
\hline LGDP & $\begin{array}{l}0.45 \\
(0.67)\end{array}$ & $\begin{array}{l}0.18 \\
(0.23)\end{array}$ & $\begin{array}{l}3.22 * \\
(1.87)\end{array}$ & $\begin{array}{l}2.75 * * \\
(2.51)\end{array}$ & $\begin{array}{l}0.49 \\
(0.31)\end{array}$ & $\begin{array}{l}1.08 \\
(1.11)\end{array}$ & $\begin{array}{l}0.76^{* * * *} \\
(5.23)\end{array}$ \\
\hline LK & $\begin{array}{l}1.05^{* *} \\
(2.16)\end{array}$ & $\begin{array}{l}-0.79 \\
(-1.33)\end{array}$ & $\begin{array}{l}-2.52 \\
(-1.50)\end{array}$ & $\begin{array}{l}-0.66 \\
(-0.92)\end{array}$ & $\begin{array}{l}-0.61 \\
(-0.41)\end{array}$ & $\begin{array}{l}-0.55 \\
(-1.04)\end{array}$ & $\begin{array}{l}-0.16 \\
(1.58)\end{array}$ \\
\hline LL & $\begin{array}{l}1.19 * \\
(1.89)\end{array}$ & $\begin{array}{l}1.47 \\
(1.35)\end{array}$ & $\begin{array}{l}0.36 \\
(0.48)\end{array}$ & $\begin{array}{l}1.56 * * * \\
(2.98)\end{array}$ & $\begin{array}{l}-0.99 \\
(-0.52)\end{array}$ & $\begin{array}{l}1.60 \\
(1.55)\end{array}$ & $\begin{array}{l}0.68 * * \\
(2.09)\end{array}$ \\
\hline LPOIL & $\begin{array}{l}-0.27 \\
(-1.17)\end{array}$ & $\begin{array}{l}-0.91 * * \\
(-2.00)\end{array}$ & $\begin{array}{l}-0.23 \\
(-0.19)\end{array}$ & $\begin{array}{l}-0.87 * * \\
(-2.71)\end{array}$ & $\begin{array}{l}0.25 \\
(0.20)\end{array}$ & $\begin{array}{l}-1.03 \\
(-1.24)\end{array}$ & $\begin{array}{l}-0.17 * * * \\
(-3.17)\end{array}$ \\
\hline LPSUB & $\begin{array}{l}0.21 \\
(0.42)\end{array}$ & - & $\begin{array}{l}-0.61 \\
(-0.32)\end{array}$ & $\begin{array}{l}0.74 * * \\
(2.20)\end{array}$ & $\begin{array}{l}-0.11 \\
(-0.03)\end{array}$ & $\begin{array}{l}1.28 \\
(1.61)\end{array}$ & - \\
\hline $\begin{array}{l}\text { Long-run } \\
\text { sigma }\end{array}$ & 0.09 & 0.24 & 0.37 & 0.07 & 0.67 & 0.13 & 0.03 \\
\hline Wald test: & $\begin{array}{l}\chi^{2}(5)= \\
252.317 \\
{[0.0000]^{* *}}\end{array}$ & $\begin{array}{l}\chi^{2}(4)= \\
23.4112 \\
{[0.0001] * *}\end{array}$ & $\begin{array}{l}\chi^{2}(5)= \\
31.157 \\
{[0.0000] * *}\end{array}$ & $\begin{array}{l}\chi^{2}(6)= \\
503.534 \\
{[0.0000] * *}\end{array}$ & $\begin{array}{l}\chi^{2}(5)= \\
0.527401 \\
{[0.9911]}\end{array}$ & $\begin{array}{l}\chi^{2}(5)= \\
205.827 \\
{[0.0000] * *}\end{array}$ & $\begin{array}{l}\chi^{2}(4)= \\
3210.22[0.0000] \\
* *\end{array}$ \\
\hline
\end{tabular}

Notes: 1. t-statistics are in ( ). 2. p-values are in [ ]. 3. ***, ** and * denote $1 \%, 5 \%$ and $10 \%$ significance level respectively.

4. $\dagger$ indicates that the trend term was included in the model specification of the Manufacturing sector as it helps improve the results comparing with the specification without the trend term. 5. The period of this study starts from 1981 to 2007.

Table 11: Constructing Error-Correction Mechanism (ECM) term by sector

\begin{tabular}{|c|c|}
\hline Sector & ECM \\
\hline Agriculture & $E C M=L O I L A G+22.89-0.45 * L G D P A G-1.05 * L K A G-1.19 * L L A G+0.27 * L P O I L A G-0.21 * L P S U B A G$ \\
\hline Construction & $E C M=$ LOILCST $-10.34-0.18 * L G D P C S T+0.79 * L K C S T-1.47 * L L C S T+0.91 * L P O I L C S T$ \\
\hline Electricity & $E C M=L O I L E L-9.10-3.22 * L G D P E L+2.52 * L K E L-0.36 * L L E L+0.24 * L P O I L E L+0.61 * L P S U B E L$ \\
\hline Manufacturing & $E C M=L O I L M F+29.25-2.75 * L G D P M F+0.66 * L K M F-1.56 * L L M F+0.87 * L P O I L M F-0.74 * L P S U B M F+0.15 * T r e n d$ \\
\hline Mining & $E C M=L O I L M N-7.99-0.50 * L G D P M N+0.62 * L K M N+0.99 * L L M N-0.25 * L P O I L M N+0.11 * L P S U B M N$ \\
\hline $\begin{array}{c}\text { Residential } \\
\text { \& Commercial }\end{array}$ & $E C M=L O I L R C+17.16-1.08 * L G D P R C+0.56 * L K R C-1.61 * L L R C+1.03 * L P O I L R C-1.28 * L P S U B R C$ \\
\hline Transportation & $E C M=L O I L T P+0.39-0.76 * L G D P T P+0.1 *^{*} L K T P-0.68 * L L T P+0.17 * L P O I L T P$ \\
\hline
\end{tabular}


Modeling Oil Demand using the ADL Single Sector Approach (1981-2007)

Table 12: The General Model of Oil Demand by sector

taking into account the effects of oil price, price of substitute energy, income, labor employment and capital stock

\begin{tabular}{|c|c|c|c|c|c|c|c|}
\hline Variable & Agriculture & Construction & Electricity & Manufacturing $\dagger$ & Mining & $\begin{array}{l}\text { Residential } \\
\text { \& Commercial }\end{array}$ & Transportation \\
\hline$\Delta$ LOIL_1 & $\begin{array}{l}0.16 \\
(0.91)\end{array}$ & $\begin{array}{l}0.23 \\
(1.39)\end{array}$ & $\begin{array}{l}0.29 \\
(0.18)\end{array}$ & $\begin{array}{l}-0.03 \\
(0.17)\end{array}$ & $\begin{array}{l}-0.13 \\
(-0.46)\end{array}$ & $\begin{array}{l}-0.02 \\
(-0.11)\end{array}$ & $\begin{array}{l}0.14 \\
(0.94)\end{array}$ \\
\hline Constant & $\begin{array}{l}0.02 \\
(0.46)\end{array}$ & $\begin{array}{l}0.03 \\
(0.622)\end{array}$ & $\begin{array}{l}0.20 \\
(0.84)\end{array}$ & $\begin{array}{l}-0.08 * * \\
(-2.96)\end{array}$ & $\begin{array}{l}-0.03 \\
(-0.14)\end{array}$ & $\begin{array}{l}0.01 \\
(0.23)\end{array}$ & $\begin{array}{l}0.001 \\
(0.11)\end{array}$ \\
\hline$\Delta$ LPOIL & $\begin{array}{l}-0.33 \\
(1.35)\end{array}$ & $\begin{array}{l}-0.32 \\
(-1.46)\end{array}$ & $\begin{array}{l}0.65 \\
(0.81)\end{array}$ & $\begin{array}{l}-0.37 * * * \\
(-3.33)\end{array}$ & $\begin{array}{l}-1.45 \\
(-1.46)\end{array}$ & $\begin{array}{l}-0.63 \\
(-1.31)\end{array}$ & $\begin{array}{l}-0.12^{* *} \\
(-2.27)\end{array}$ \\
\hline$\Delta$ LPOIL_1 & $\begin{array}{l}0.22^{* *} \\
(-2.09)\end{array}$ & $\begin{array}{l}0.38 \\
(1.39)\end{array}$ & $\begin{array}{l}1.01 \\
(1.19)\end{array}$ & $\begin{array}{l}0.11 \\
(0.83)\end{array}$ & $\begin{array}{l}-0.40 \\
(-0.386)\end{array}$ & $\begin{array}{l}0.36 \\
(0.84)\end{array}$ & $\begin{array}{l}-0.06 \\
(-0.799)\end{array}$ \\
\hline$\Delta$ LPSUB & $\begin{array}{l}0.01 \\
(0.02)\end{array}$ & - & $\begin{array}{l}0.07 \\
(0.06)\end{array}$ & $\begin{array}{l}0.17 \\
(1.09)\end{array}$ & $\begin{array}{l}-0.86 \\
(-0.50)\end{array}$ & $\begin{array}{l}-0.29 \\
(-0.62)\end{array}$ & - \\
\hline$\Delta$ LPSUB_1 & $\begin{array}{l}-0.17 \\
(-0.72)\end{array}$ & - & $\begin{array}{l}-0.82 \\
(-0.69)\end{array}$ & $\begin{array}{l}-0.24 \\
(-1.37)\end{array}$ & $\begin{array}{l}0.25 \\
(0.16)\end{array}$ & $\begin{array}{l}-0.84 \\
(-1.24)\end{array}$ & - \\
\hline$\Delta_{\text {LGDP }}$ & $\begin{array}{l}-0.25 \\
(-0.52)\end{array}$ & $\begin{array}{l}-0.20 \\
(-0.575)\end{array}$ & $\begin{array}{l}-1.59 \\
(-1.03)\end{array}$ & $\begin{array}{l}1.76^{* * * *} \\
(5.47)\end{array}$ & $\begin{array}{l}2.55 \\
(1.50)\end{array}$ & $\begin{array}{l}0.48 \\
(0.74)\end{array}$ & $\begin{array}{l}0.74 * * * \\
(3.75)\end{array}$ \\
\hline$\Delta$ LGDP_1 & $\begin{array}{l}-0.49 \\
(-0.86)\end{array}$ & $\begin{array}{l}-0.58 \\
(-1.52)\end{array}$ & $\begin{array}{l}-2.81 \\
(-1.55)\end{array}$ & $\begin{array}{l}0.12 \\
(0.51)\end{array}$ & $\begin{array}{l}0.71 \\
(0.408)\end{array}$ & $\begin{array}{l}0.79 \\
(0.88)\end{array}$ & $\begin{array}{l}-0.03 \\
(-0.14)\end{array}$ \\
\hline$\Delta_{\mathrm{LK}}$ & $\begin{array}{l}-3.22^{* * * *} \\
(-3.33)\end{array}$ & $\begin{array}{l}-3.02 * * * \\
(-3.33)\end{array}$ & $\begin{array}{l}10.80^{* *} \\
(1.88)\end{array}$ & $\begin{array}{l}-4.64 * * * \\
(-4.81)\end{array}$ & $\begin{array}{l}0.74 \\
(0.27)\end{array}$ & $\begin{array}{l}-0.61 * * \\
(-2.06)\end{array}$ & $\begin{array}{l}0.02 \\
(0.06)\end{array}$ \\
\hline$\Delta$ LK_1 & $\begin{array}{l}-1.65 \\
(-0.89)\end{array}$ & $\begin{array}{l}-0.11 \\
(-0.145)\end{array}$ & $\begin{array}{l}5.12 \\
(0.65)\end{array}$ & $\begin{array}{l}-0.96 \\
(-0.80)\end{array}$ & $\begin{array}{l}-1.23 \\
(-0.42)\end{array}$ & $\begin{array}{l}-0.15 \\
(-0.64)\end{array}$ & $\begin{array}{l}0.30 \\
(0.91)\end{array}$ \\
\hline$\Delta \mathrm{LL}$ & $\begin{array}{l}0.20 \\
(0.58)\end{array}$ & $\begin{array}{l}1.86^{* * * *} \\
(4.60)\end{array}$ & $\begin{array}{l}-0.29 \\
(-0.51)\end{array}$ & $\begin{array}{l}0.71^{* * *} \\
(3.38)\end{array}$ & $\begin{array}{l}-0.19 \\
(-0.35)\end{array}$ & $\begin{array}{l}0.59 \\
(1.34)\end{array}$ & $\begin{array}{l}0.34^{* *} \\
(2.65)\end{array}$ \\
\hline$\Delta$ LL_1 & $\begin{array}{l}-0.30 \\
(-0.86)\end{array}$ & $\begin{array}{l}-0.77^{* *} \\
(-1.99)\end{array}$ & $\begin{array}{l}-0.73 \\
(-1.50)\end{array}$ & $\begin{array}{l}-0.09 \\
(-0.42)\end{array}$ & $\begin{array}{l}-0.11 \\
(-0.22)\end{array}$ & $\begin{array}{l}-0.49 \\
(-0.95)\end{array}$ & $\begin{array}{l}-0.11 \\
(-0.96)\end{array}$ \\
\hline ECM_1 & $\begin{array}{l}-0.97 * * * \\
(-3.43)\end{array}$ & $\begin{array}{l}-1.28 * * * \\
(-7.20)\end{array}$ & $\begin{array}{l}-1.08 * * * \\
(-3.93)\end{array}$ & $\begin{array}{l}-0.79 * * * \\
(-3.97)\end{array}$ & $\begin{array}{l}-0.57 * * \\
(-2.12)\end{array}$ & $\begin{array}{l}-0.93 * * * \\
(-3.41)\end{array}$ & $\begin{array}{l}-0.91 * * * \\
(-3.45)\end{array}$ \\
\hline \multicolumn{8}{|c|}{ Test Summary } \\
\hline AR 1-2 test: & $\begin{array}{l}F(2,10)= \\
0.97699 \\
{[0.4097]}\end{array}$ & $\begin{array}{l}F(2,12)= \\
0.64169 \\
{[0.5435]}\end{array}$ & $\begin{array}{l}\mathrm{F}(2,10)= \\
0.92615 \\
{[0.4276]}\end{array}$ & $\begin{array}{l}\mathrm{F}(2,10)= \\
1.4513 \\
{[0.2796]}\end{array}$ & $\begin{array}{l}\mathrm{F}(2,10)= \\
2.7723 \\
{[0.1102]}\end{array}$ & $\begin{array}{l}\mathrm{F}(2,10)= \\
1.2835 \\
{[0.3190]}\end{array}$ & $\begin{array}{l}\mathrm{F}(2,12)= \\
0.17480 \\
{[0.8417]}\end{array}$ \\
\hline ARCH 1-1 test: & $\begin{array}{l}F(1,10)= \\
0.27967 \\
{[0.6085]}\end{array}$ & $\begin{array}{l}F(1,12) \\
=0.0020669 \\
{[0.9645]}\end{array}$ & $\begin{array}{l}\mathrm{F}(1,10)= \\
1.5218 \\
{[0.2456]}\end{array}$ & $\begin{array}{l}\mathrm{F}(1,10)= \\
0.55717 \\
{[0.4726]}\end{array}$ & $\begin{array}{l}\mathrm{F}(1,10)= \\
3.6155 \\
{[0.0864]}\end{array}$ & $\begin{array}{l}\mathrm{F}(1,10)= \\
1.7140 \\
{[0.2198]}\end{array}$ & $\begin{array}{l}\mathrm{F}(1,12)= \\
0.26958 \\
{[0.6131]}\end{array}$ \\
\hline Normality test & $\begin{array}{c}\chi^{2}(2)= \\
3.1899 \\
{[0.2029]}\end{array}$ & $\begin{array}{r}\chi^{2}(2)= \\
4.1224 \\
{[0.1273]}\end{array}$ & $\begin{array}{l}\chi^{2}(2)= \\
1.7079 \\
{[0.4257]}\end{array}$ & $\begin{array}{l}\chi^{2}(2)= \\
4.9430 \\
{[0.0845]}\end{array}$ & $\begin{array}{l}\chi^{2}(2)= \\
4.0292 \\
{[0.1334]}\end{array}$ & $\begin{array}{l}\chi^{2}(2)= \\
9.1529 \\
{[0.0103]^{*}}\end{array}$ & $\begin{array}{l}\chi^{2}(2)= \\
1.0093 \\
{[0.6037]}\end{array}$ \\
\hline Reset test: & $\begin{array}{l}\mathrm{F}(1,11)= \\
13.281 \\
{[0.0039]^{* *}}\end{array}$ & $\begin{array}{l}\mathrm{F}(1,13)= \\
0.26478 \\
{[0.6155]}\end{array}$ & $\begin{array}{l}\mathrm{F}(1,11)= \\
1.5676 \\
{[0.2365]}\end{array}$ & $\begin{array}{l}\mathrm{F}(1,11)= \\
1.3054 \\
{[0.2775]}\end{array}$ & $\begin{array}{l}\mathrm{F}(1,11)= \\
26.064 \\
{[0.0003]^{* *}}\end{array}$ & $\begin{array}{l}\mathrm{F}(1,11)= \\
1.0618 \\
{[0.3249]}\end{array}$ & $\begin{array}{l}\mathrm{F}(1,13)= \\
0.54500 \\
{[0.4735]}\end{array}$ \\
\hline
\end{tabular}

Notes: $1 .{ }^{* * *}, * *$ and $*$ denote $1 \%, 5 \%$ and $10 \%$ significance level respectively.

2. $t$-statistics are in ( ).

3. p-values are in [].

4. † indicates that in the Manufacturing sector the ECM term with trend has been used in the General Model. 
Modeling Oil Demand using the ADL Single Sector Approach (1981-2007)

Table 13: The Specific Model of Oil Demand by sector

taking into account the effects of oil price, price of substitute energy, income, labor employment and capital stock

\begin{tabular}{|c|c|c|c|c|c|c|c|}
\hline Variable & Agriculture & Construction & Electricity & Manufacturing $\dagger$ & Mining & $\begin{array}{l}\text { Residential } \\
\text { \& Commercial }\end{array}$ & Transportation \\
\hline Constant & & & & $\begin{array}{l}-0.09 * * * \\
(-5.85)\end{array}$ & & & \\
\hline$\Delta \mathrm{LGDP}$ & & & & $\begin{array}{l}1.58^{* * *} \\
(6.82)\end{array}$ & $\begin{array}{l}2.14^{* *} \\
(2.73)\end{array}$ & $\begin{array}{l}1.21^{* * *} \\
(4.66)\end{array}$ & $\begin{array}{l}0.94 * * * \\
(13.5)\end{array}$ \\
\hline$\Delta$ LGDP_1 & & $\begin{array}{l}-0.79 * * \\
(-2.78)\end{array}$ & & & & & \\
\hline$\Delta_{\mathrm{LK}}$ & $\begin{array}{l}-3.26 * * * \\
(-5.28)\end{array}$ & $\begin{array}{l}-2.4^{* * *} \\
(-5.93)\end{array}$ & $\begin{array}{l}10.74^{* * * *} \\
(6.76)\end{array}$ & $\begin{array}{l}-3.99 * * * \\
(-5.67)\end{array}$ & & $\begin{array}{l}-0.40 * * * \\
(-3.09)\end{array}$ & \\
\hline$\Delta_{\mathrm{LL}}$ & $\begin{array}{l}0.32 * \\
(1.76)\end{array}$ & $\begin{array}{l}1.45^{* * * *} \\
(4.85)\end{array}$ & & $\begin{array}{l}0.66^{* * *} \\
(3.80)\end{array}$ & & & $\begin{array}{l}0.39 * * * \\
(4.18)\end{array}$ \\
\hline$\Delta$ LPOIL & $\begin{array}{l}-0.24 * * \\
(-2.44)\end{array}$ & & $\begin{array}{l}1.47^{* * *} \\
(3.00)\end{array}$ & $\begin{array}{l}-0.24^{* * *} \\
(-3.10)\end{array}$ & $\begin{array}{l}-1.73 * * * \\
(-3.47)\end{array}$ & $\begin{array}{l}-0.79 * * * \\
(-3.21)\end{array}$ & $\begin{array}{l}-0.16^{* * *} \\
(-3.11)\end{array}$ \\
\hline$\Delta$ LPSUB & & & & & $\begin{array}{l}-1.11 \\
(-1.02)\end{array}$ & & \\
\hline ECM_1 & $\begin{array}{l}-0.74 * * * \\
(-6.83)\end{array}$ & $\begin{array}{l}-1.01^{* * *} \\
(-7.69)\end{array}$ & $\begin{array}{l}-0.81 * * * \\
(-7.08)\end{array}$ & $\begin{array}{l}-0.59 * * * \\
(-6.83)\end{array}$ & $\begin{array}{l}-0.51 * * * \\
(-4.27)\end{array}$ & $\begin{array}{l}-0.64 * * * \\
(-5.50)\end{array}$ & $\begin{array}{l}-0.55^{* * *} \\
(-4.17)\end{array}$ \\
\hline Dummy 1983 & & & & & & $\begin{array}{l}0.25 * * * \\
(-4.16)\end{array}$ & \\
\hline \multicolumn{8}{|c|}{ Test Summary } \\
\hline AR 1-2 test: & $\begin{array}{l}\mathrm{F}(2,19)= \\
0.037530 \\
{[0.9632]}\end{array}$ & $\begin{array}{l}\mathrm{F}(2,19)= \\
0.023982 \\
{[0.9763]}\end{array}$ & $\begin{array}{l}\mathrm{F}(2,20)= \\
0.12864 \\
{[0.8800]}\end{array}$ & $\begin{array}{l}\mathrm{F}(1,17)= \\
0.66489 \\
{[0.5272]}\end{array}$ & $\begin{array}{l}F(2,19)= \\
0.28163 \\
{[0.7576]}\end{array}$ & $\begin{array}{l}\mathrm{F}(2,18)= \\
0.52501 \\
{[0.6003]}\end{array}$ & $\begin{array}{l}\mathrm{F}(2,19)= \\
0.41956 \\
{[0.6633]}\end{array}$ \\
\hline ARCH 1-1 test: & $\begin{array}{l}F(1,19)= \\
0.36505 \\
{[0.5529]}\end{array}$ & $\begin{array}{l}F(1,19) \\
=0.0034011 \\
{[0.9541]}\end{array}$ & $\begin{array}{l}\mathrm{F}(1,20)= \\
0.29203 \\
{[0.5949]}\end{array}$ & $\begin{array}{l}\mathrm{F}(1,17)= \\
0.020972 \\
{[0.8866]}\end{array}$ & $\begin{array}{l}\mathrm{F}(1,19)= \\
5.3151 \\
{[0.0326]^{*}}\end{array}$ & $\begin{array}{l}\mathrm{F}(1,18)= \\
0.54240 \\
{[0.4709]}\end{array}$ & $\begin{array}{l}\mathrm{F}(1,19)= \\
1.8714[0.1873]\end{array}$ \\
\hline Normality test & $\begin{array}{c}\chi^{2}(2)= \\
2.9267 \\
{[0.2315]}\end{array}$ & $\begin{array}{r}\chi^{2}(2)= \\
2.7966 \\
{[0.2470]}\end{array}$ & $\begin{array}{c}\chi^{2}(2)= \\
0.96329 \\
{[0.6178]}\end{array}$ & $\begin{array}{c}\chi^{2}(2)= \\
0.30051 \\
{[0.8605]}\end{array}$ & $\begin{array}{l}\chi^{2}(2)= \\
3.1036 \\
{[0.2119]}\end{array}$ & $\begin{array}{l}\chi^{2}(2)= \\
7.7895 \\
{[0.0203]^{*}}\end{array}$ & $\begin{array}{l}\chi^{2}(2)= \\
4.0372 \\
{[0.1328]}\end{array}$ \\
\hline Hetero test: & $\begin{array}{l}\mathrm{F}(8,12)= \\
4.4005 \\
{[0.0109]^{*}}\end{array}$ & $\begin{array}{l}\mathrm{F}(8,12)= \\
1.1384 \\
{[0.4051]}\end{array}$ & $\begin{array}{l}\mathrm{F}(6,15)= \\
3.7616 \\
{[0.0174]^{*}}\end{array}$ & $\begin{array}{l}\mathrm{F}(10,8)= \\
0.38630 \\
{[0.9197]}\end{array}$ & $\begin{array}{l}F(8,12)= \\
0.68827 \\
{[0.6958]}\end{array}$ & $\begin{array}{l}\mathrm{F}(9,10)= \\
3.1529 \\
{[0.0440]^{*}}\end{array}$ & $\begin{array}{l}F(8,12)= \\
0.75955 \\
{[0.6434]}\end{array}$ \\
\hline Reset test: & $\begin{array}{l}\mathrm{F}(1,20)= \\
7.7173 \\
{[0.0116]^{*}}\end{array}$ & $\begin{array}{l}\mathrm{F}(1,20)= \\
0.30649 \\
{[0.5860]}\end{array}$ & $\begin{array}{l}\mathrm{F}(1,21)= \\
0.18740 \\
{[0.6695]}\end{array}$ & $\begin{array}{l}\mathrm{F}(1,18)= \\
3.6847 \\
{[0.0709]}\end{array}$ & $\begin{array}{l}\mathrm{F}(1,20)= \\
13.572 \\
{[0.0015]^{* *}}\end{array}$ & $\begin{array}{l}\mathrm{F}(1,19)= \\
3.8900 \\
{[0.0633]}\end{array}$ & $\begin{array}{l}\mathrm{F}(1,20)= \\
0.021020 \\
{[0.8862]}\end{array}$ \\
\hline
\end{tabular}

Notes: 1. The automatic model selection (Autometrics) is a useful feature in PcGive often used to perform general-to-specific modeling approach by searching through many available reduction paths and selecting the best model that can pass a set of statistical criteria. In this study, the criteria assigning for Autometrics are target size: 0.05 and Outlier detection: Large residuals. For more details please consult Doornik and Hendry (2007).

2. In each sector, the general model before applying Autometrics is of the form:

$\Delta L O I L_{t}=\beta_{0}+\beta_{1} \Delta L O I L_{t-1}+\beta_{2} \Delta L P O I L_{t}+\beta_{3} \Delta L$ LOIL L $_{t-1}+\beta_{4} \Delta L P S U B_{t}+\beta_{5} \Delta L P S U B_{t-1}+\beta_{6} \Delta L G D P_{t}+\beta_{7} \Delta L G D P_{t-1}+\beta_{8} \Delta L K_{t}+\beta_{9} \Delta L K_{t-1}+\beta_{10} \Delta L L_{t}+\beta_{11} \Delta L L_{t-1}+\beta_{12} E C M_{t-1}+e_{t}$

3. $* * *, * *$ and $*$ denote $1 \%, 5 \%$ and $10 \%$ significance level respectively.

4. $t$-statistics are in ( ). 5. p-values are in [ ]

6. † indicates that in the Manufacturing sector the ECM term with trend has been used in the General Model. 
Modeling Oil Demand using the Dynamic Panel Data Approach (1981-2007)

Table 14A: The estimated coefficients from Dynamic Panel Data Approach

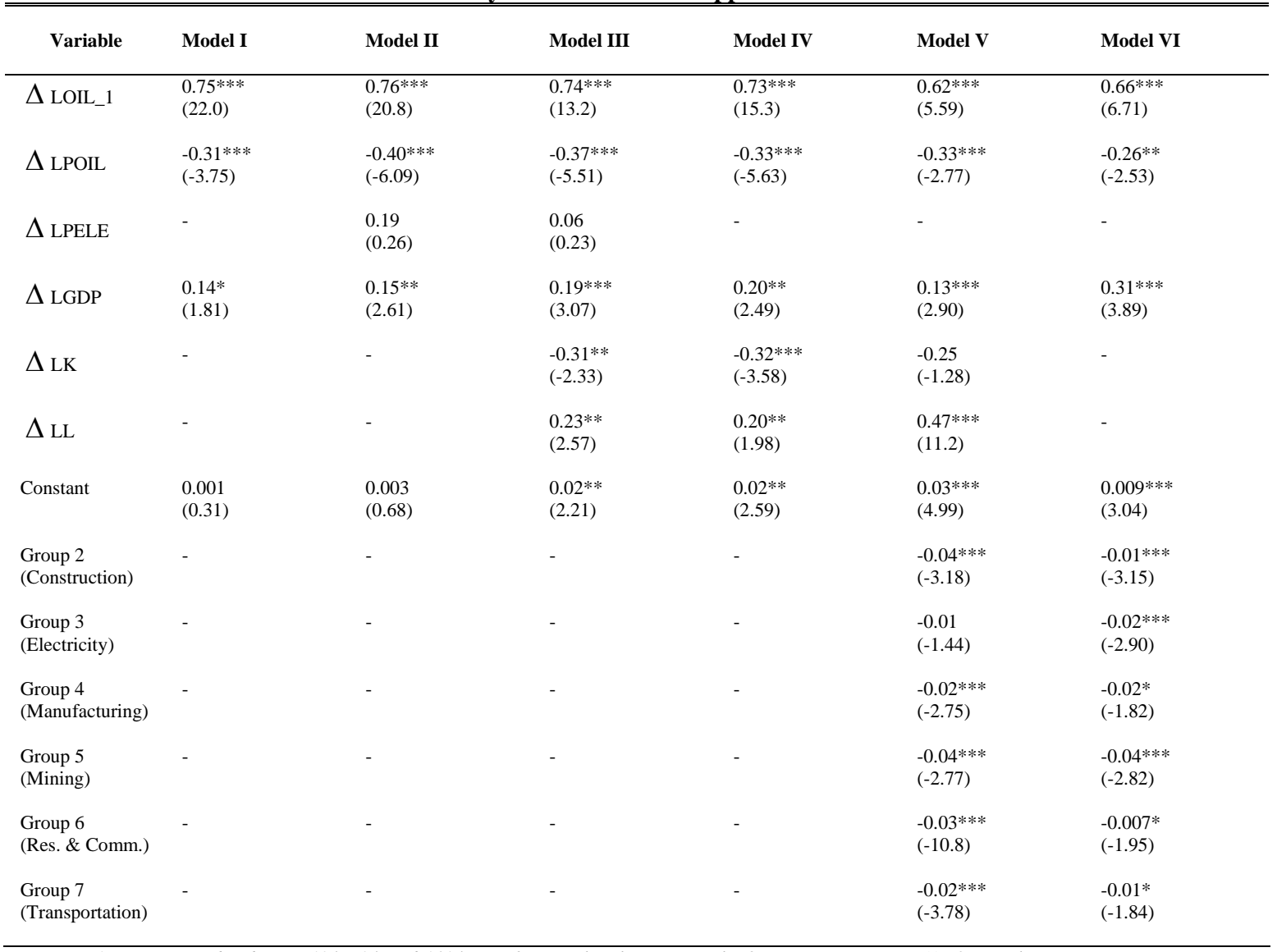

Notes: $1 . * * *, * *$ and $*$ denote $1 \%, 5 \%$ and $10 \%$ significance level respectively. $2 . t$-statistics are in ( ). 3. p-values are in [ ].

Table 14B: Test Summary of the Dynamic Panel Data Approach

\begin{tabular}{|c|c|c|c|c|c|c|}
\hline & Model I & Model II & Model III & Model IV & Model V & Model VI \\
\hline Wald (joint): & $\begin{array}{l}\chi^{2}(3)= \\
715.3 \\
{[0.000] * *}\end{array}$ & $\begin{array}{l}\chi^{2}(4)= \\
873.7 \\
{[0.000] * *}\end{array}$ & $\begin{array}{l}\chi^{2}(6)= \\
2221 . \\
{[0.000] * *}\end{array}$ & $\begin{array}{l}\chi^{2}(5)= \\
1995 . \\
{[0.000] * *}\end{array}$ & $\begin{array}{l}\chi^{2}(5)= \\
2967 . \\
{[0.000] * *}\end{array}$ & $\begin{array}{l}\chi^{2}(3)= \\
236.8 \\
{[0.000] * *}\end{array}$ \\
\hline Wald (dummy): & $\begin{array}{l}\chi^{2}(1)= \\
0.09424 \\
{[0.759]}\end{array}$ & $\begin{array}{l}\chi^{2}(1)= \\
0.4627 \\
{[0.496]}\end{array}$ & $\begin{array}{l}\chi^{2}(1)= \\
4.903 \\
{[0.027] *}\end{array}$ & $\begin{array}{l}\chi^{2}(1)= \\
6.685 \\
{[0.010] * *}\end{array}$ & $\begin{array}{l}\chi^{2}(7)= \\
1.636 \mathrm{e}+010 \\
{[0.000] * *}\end{array}$ & $\begin{array}{l}\chi^{2}(7)= \\
41.53 \\
{[0.000] * *}\end{array}$ \\
\hline Sargan test: & $\begin{array}{l}\chi^{2}(322)= \\
168.9 \\
{[1.000]}\end{array}$ & $\begin{array}{l}\chi^{2}(321)= \\
150.6 \\
{[1.000]}\end{array}$ & $\begin{array}{l}\chi^{2}(324)= \\
149.7 \\
{[1.000]}\end{array}$ & $\begin{array}{l}\chi^{2}(324)= \\
164.8 \\
{[1.000]}\end{array}$ & $\begin{array}{l}\chi^{2}(325)= \\
172.1 \\
{[1.000]}\end{array}$ & $\begin{array}{l}\chi^{2}(322)= \\
170.3 \\
{[1.000]}\end{array}$ \\
\hline AR(1) test: & $\begin{array}{l}\mathrm{N}(0,1)= \\
-1.345 \\
{[0.179]}\end{array}$ & $\begin{array}{l}\mathrm{N}(0,1)= \\
-1.349 \\
{[0.177]}\end{array}$ & $\begin{array}{l}\mathrm{N}(0,1)= \\
-1.364 \\
{[0.173]}\end{array}$ & $\begin{array}{l}\mathrm{N}(0,1)= \\
-1.354 \\
{[0.176]}\end{array}$ & $\begin{array}{l}\mathrm{N}(0,1)= \\
-1.400 \\
{[0.162]}\end{array}$ & $\begin{array}{l}\mathrm{N}(0,1)= \\
-1.402 \\
{[0.161]}\end{array}$ \\
\hline AR(2) test: & $\begin{array}{l}\mathrm{N}(0,1)= \\
1.237 \\
{[0.216]}\end{array}$ & $\begin{array}{l}\mathrm{N}(0,1)= \\
1.233 \\
{[0.218]}\end{array}$ & $\begin{array}{l}\mathrm{N}(0,1)= \\
1.228 \\
{[0.220]}\end{array}$ & $\begin{array}{l}\mathrm{N}(0,1)= \\
1.222 \\
{[0.222]}\end{array}$ & $\begin{array}{l}\mathrm{N}(0,1)= \\
1.175 \\
{[0.240]}\end{array}$ & $\begin{array}{l}\mathrm{N}(0,1)= \\
1.244 \\
{[0.213]}\end{array}$ \\
\hline
\end{tabular}


Modeling Oil Demand using the Dynamic Panel Data Approach (1981-2007)

Table 15: Elasticity values of Oil Demand with respect to interested variables from Dynamic Panel Data Approach

\begin{tabular}{lllllll}
\hline & Model I & Model II & Model III & Model IV & Model V & Model VI \\
\hline $\begin{array}{llllll}\text { SR Price } \\
\text { Elasticity }\end{array}$ & -0.31 & -0.40 & -0.37 & -0.33 & -0.33 & -0.26 \\
$\begin{array}{l}\text { LR Price } \\
\text { Elasticity }\end{array}$ & -1.28 & -1.70 & -1.42 & -1.27 & -0.88 & -0.76 \\
$\begin{array}{l}\text { SR Income } \\
\text { Elasticity }\end{array}$ & 0.14 & 0.15 & 0.20 & 0.20 & 0.13 & 0.31 \\
$\begin{array}{l}\text { LR Income } \\
\text { Elasticity }\end{array}$ & 0.57 & 0.64 & 0.75 & 0.77 & 0.34 & 0.92 \\
$\begin{array}{l}\text { SR Capital } \\
\text { Elasticity }\end{array}$ & n.a. & n.a. & -0.31 & -0.32 & -0.25 & n.a. \\
$\begin{array}{l}\text { LR Capital } \\
\text { Elasticity }\end{array}$ & n.a. & n.a. & -1.19 & -1.19 & -0.66 & n.a. \\
$\begin{array}{l}\text { SR Labor } \\
\text { Elasticity }\end{array}$ & n.a. & n.a. & 0.23 & 0.20 & 0.47 & n.a. \\
$\begin{array}{l}\text { LR Labor } \\
\text { Elasticity }\end{array}$ & n.a. & n.a. & 0.88 & 0.74 & 1.24 & n.a. \\
\hline
\end{tabular}

